Historic, Archive Document

Do not assume content reflects current scientific knowledge, policies, or practices. 
. 


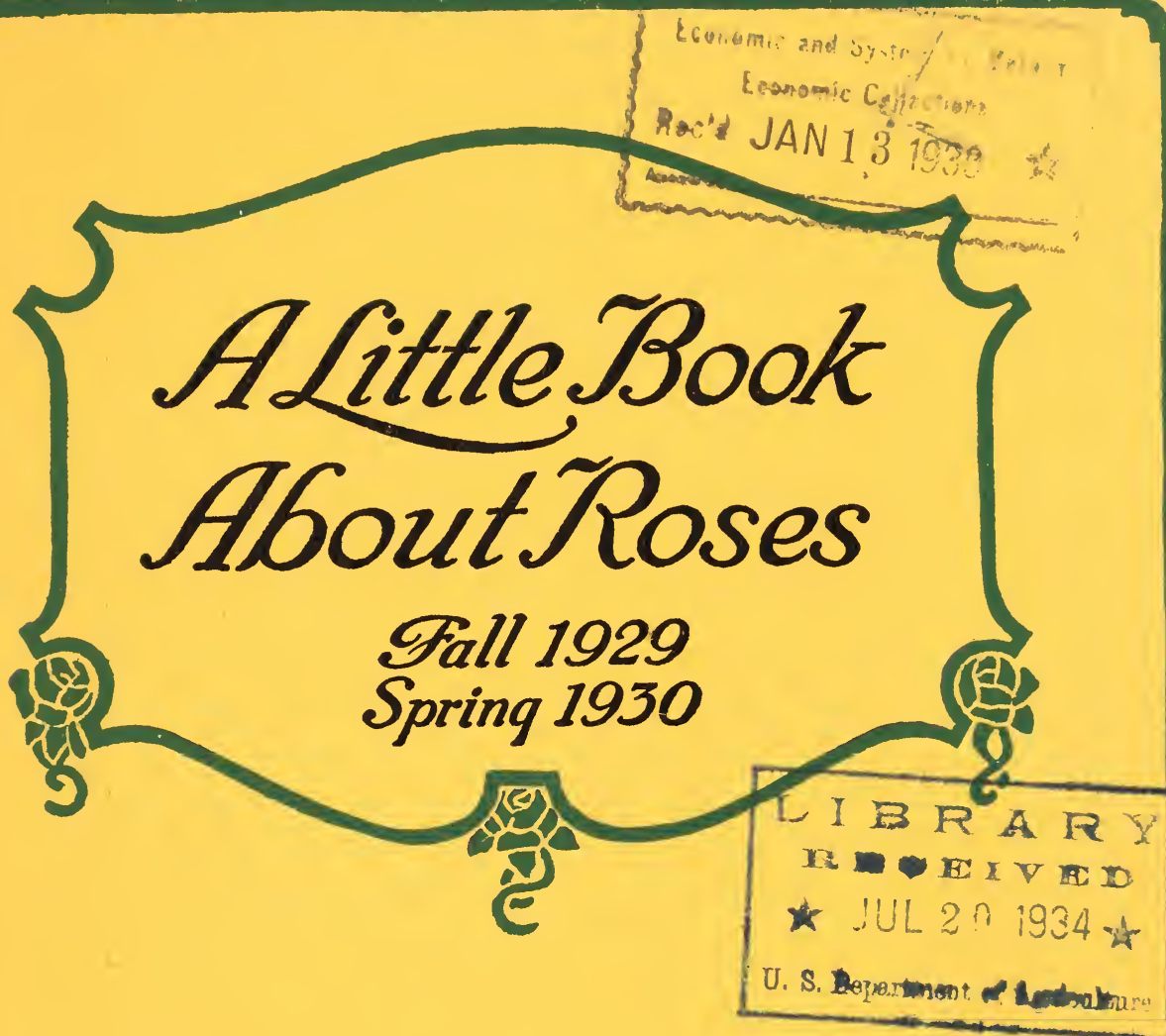




\section{The Peony}

GRANDEST of all outdoor flowers, $T$ easiest of all to grow, as well as the most sure and permanent, the modern varieties of the Peony will prove both a revelation and rare delight to the flower lover.

Our Peonies, like our Roses, are recognized by experienced buyers to be the very best that a lifetime of skilled and loving effort can produce.

Peony roots are shipped in a completely dormant state during the months of September and October.

A copy of "The Flower Beautiful," the only exclusive Peony catalog that has been published annually for 25 years, will be sent upon request. 

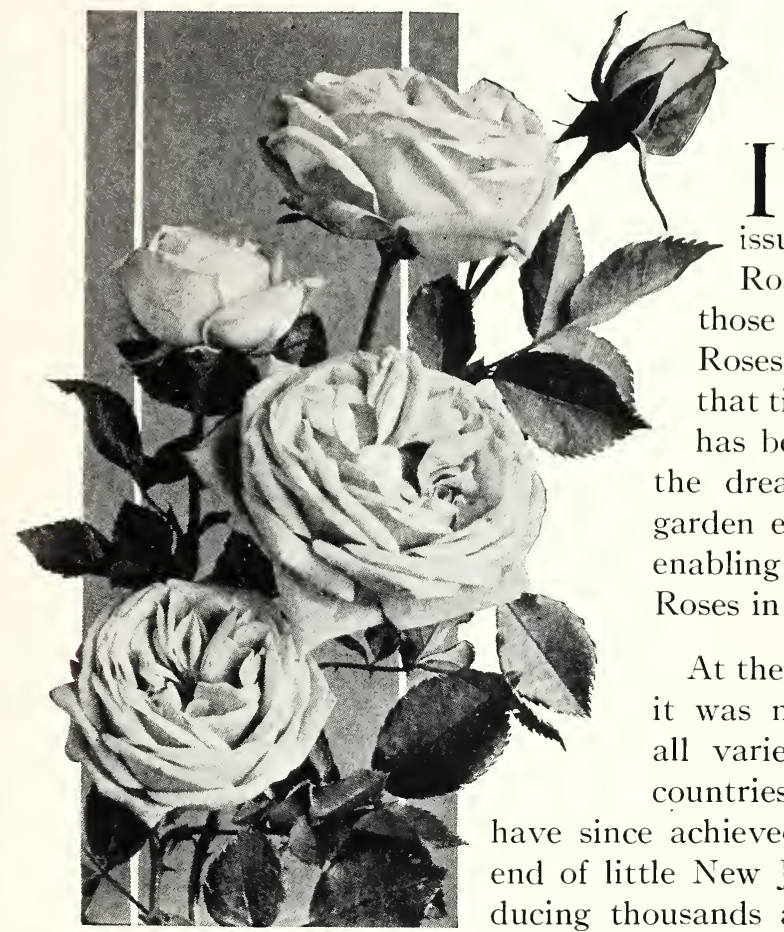

\section{FOREWORD}

T $T$ is exactly a quarter of a century ago that the first yearly issue of "A Little Book About Roses" was sent into the homes of those who desired to know and plant Roses outdoors in America. From that time on, the business it represents has been most influential in bringing the dreams and hopes of many true garden enthusiasts to a full realization, enabling them to enjoy really good Roses in their own gardens.

At the time this business was founded, it was necessary to import practically all varieties of Roses from European countries. But consider the progress we have since achieved! Right here in the northern end of little New Jersey, we are successfully producing thousands and thousands of Rose bushes under the open skies. All of them are two years old, budded and grown on the strongest understock we know of. They are grown with only one end in view: to produce a hardened, well-ripened, and mature bush that may be dug and safely shipped and planted in all parts of the country.

While it is true that our business in Roses has grown appreciably during its many years of existence, still we hope never to outgrow ourselves to the point that you may not feel that same touch of personality which has always accompanied our relations with both old and new patrons. Even though all about us, and in the Rose business, too, we hear of large-scale production methods and of mergers in all lines of business, let us remind you that here is one little, highly specialized business that modestly awaits your patronage. You may thoroughly relax when once your order is dispatched, and feel confident that your "Roses from Peterson" will arrive at the right time and in the best possible condition. 


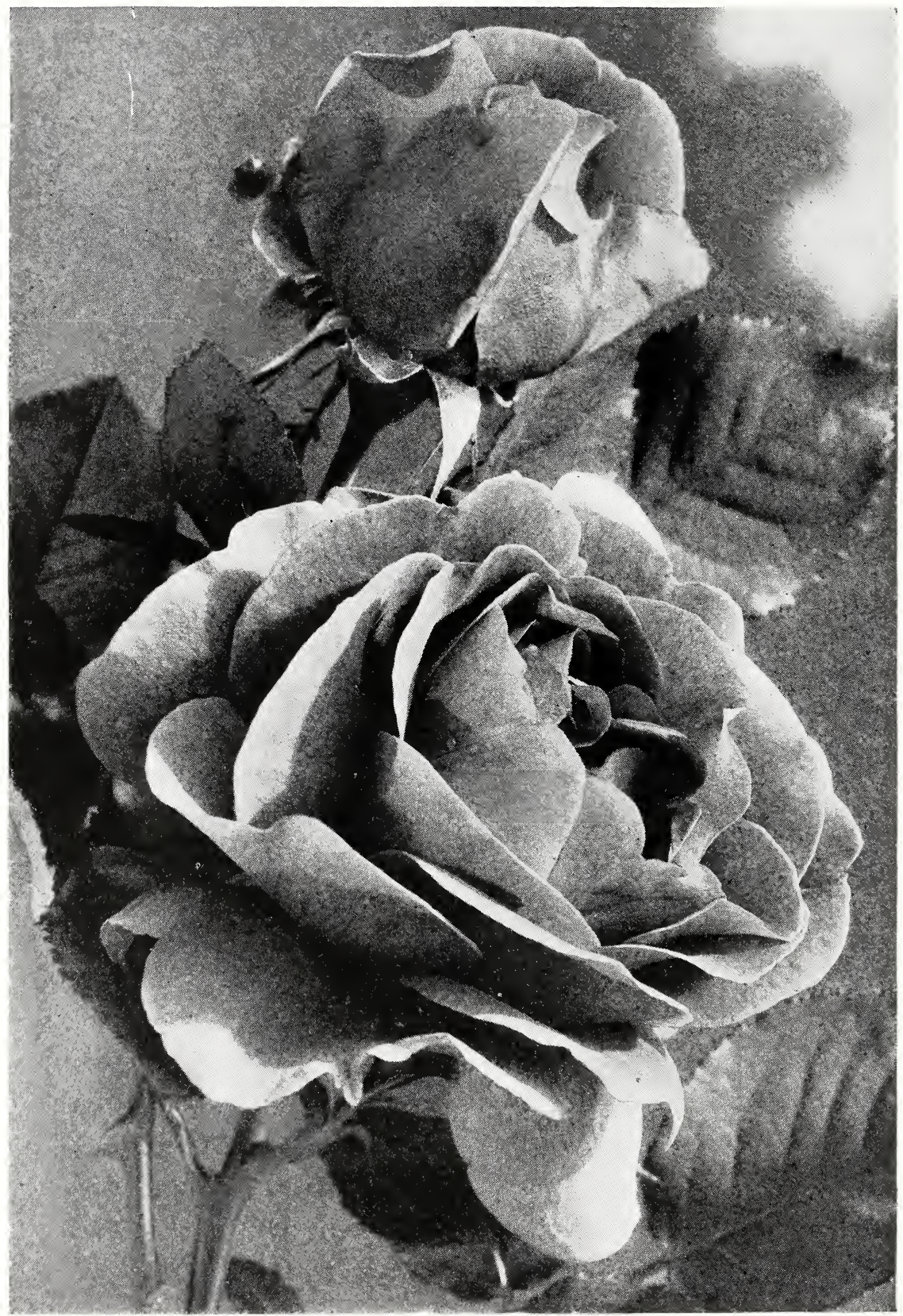

Margaret McGredy. See page 14 
Y OUR attention is kindly called to the arrangement of our writings in this little book. The first few pages are preliminary and timely remarks for the prospective buyer, both old and new. Then follow the three classes of Roses: Hybrid Teas, page 7; Hybrid Perpetuals, page 20; and Climbers, page 23. Pages 25 to $3 \mathrm{I}$ are devoted to cultural methods. On the last page are typical experiences of some of our customers.

\section{Planting Seasons for Dormant Roses}

Fall shipping season begins in early October and continues on through the month of November. Spring season from the middle of March until the end of April; after that buy potted Roses. See page $3 I$.

$\mathrm{O}^{\prime}$ UR PATRONS for the past few years know that we have continually recommended the fall of the year as being the ideal time to plant Roses. It is still our opinion, as well as that of professionals and advanced a mateurs, that the fall season offers many advantages as we enumerated them in our last year's catalog. No less an authority than Dr. J. Horace McFarland, now President of The American Rose Society, has repeatedly brought to light, in the last few years, the advantages of fall planting. However, our experience plainly showed that there were too many potential customers who found it inconvenient to plant, or else whose enthusiasm in the fall simply could not be worked up to such a degree as to enable them conscientiously to plant just before winter sets in.

It is true that in the fall, stocks in all varieties are complete and fresh. Furthermore, plants will become established in the garden and be ready to go ahead in the spring and produce a bumper crop of Roses in June more readily than spring-planted stock. Many of our recent big civic plantings, as well as those supervised by prominent Landscape Architects on big estates, have been most successfully planted in the fall.

There is bound to be controversy on the "Fall versus Spring Planting" subject just as long as there are Roses planted. It is now a matter many of you must decide for yourselves. Your past personal experiences under local climatic conditions will in many cases be a guide. We know the many experienced fall planters of Peterson's Roses for the past five or six years will be guided by their past success.

At any rate, whether you want your Roses this fall or next spring, the House of Peterson is better equipped than ever to satisfy your needs. The new storage and packing sheds with office adjoining, only recently completed, make it possible for us to cater to all Rose lovers throughout the planting seasons.

\section{A Word about New Varieties}

In writing the descriptions and comments on certain varieties of Hybrid Teas which we offer for the first time, we have purposely been rather outspoken in our opinions. The Rosebuying public demands all that is new and interesting in Roses, and rightly so. Quite a few recent European introductions have been disseminated in this country and, while the individual flowers from newly-budded stock in the field are most charming indeed, and give us colors totally different from older varieties in commerce, still the constitution of the plant the following year does not seem to be adapted to our varying climatic conditions.

Determining the merits of a newly introduced variety on the basis of the flowers alone seems to us to be a very unfair basis for judgment. In our visits both to private and commercial plantings, and in our own fields this summer, there were times when we were much disappointed upon observing new varieties which were not giving a good account of themselves. But how our spirits rose, and what a real thrill we got upon beholding an older variety-yes, maybe a nearly forgotten one-standing up as though to say, "Well, what's the matter with me?"

Critics will reply to this little discourse that all of our older varieties were once novelties. Wasn't Frau Karl Druschki once a novelty which we did not know would stay or not? The point we make is that during the past few years there seem to have been just a few too many new varieties that have been loudly praised and advertised before we really knew much about them. Please understand that we fully realize many of you are perfectly willing to buy new varieties, not yet so thoroughly tested, for the thrill and excitement accompanying that anticipation of admiring a Rose you have never seen before. 


\section{The Stock We Send Out}

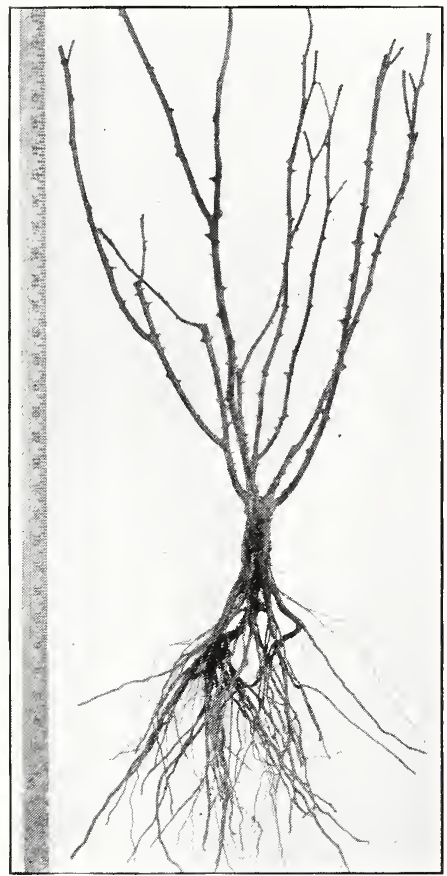

Dormant Hybrid Tea Rose Plant

Our Fose plants are all born and reared out-of-doorshave never even seen a greenhouse-and are, in consequence, very much more able to endure and thrive in garden culture than Roses reared in the tropical atmosphere under glass.

They are practically all grown and outdoor budded on the Japanese polyantha multiflora. This stock produces a wonderful root system, infuses vigor and hardiness into the cultivated variety budded on it, and, what is of most desired importance, it practically never throws up a wild sucker or growth from the root.

In late November the seed is sown in huge beds in the open ground and the seedlings begin to appear above ground in April. All that summer the beds must be carefully handweeded-a tedious operation-and in the late fall these one-year seedlings are dug. They then range in height from 10 inches to 2 feet and in thickness, at the base, from that of a darning needle, or even smaller, to a lead pencil. They are packed away in damp moss in huge cases and in the winter these seedlings are assorted into four sizes. The top $2 \mathrm{I} / 2$ inches of the root is cleaned of all rootlets so that the bud of the desired variety can be readily inserted the following summer.

In April following, these seedlings are planted in rows in the field, each size in a block by itself. The budding of these is done from June 20 to the end of August. The plant now stays out-of-doors all the following winter.

In March, and we are now entering the third year, the wild part of the plant is cut off just above where the bud was inserted, and this means within an inch of the ground. While the majority of the buds will have remained dormant until now, many of the buds inserted during the first half of the budding period will have made a growth the same summer as budded of from I to 3 feet. This is usually one single cane and it, too, is cut back in March to the last eye or within an inch of the base.

During the third and last year of the nursery growth, with the advent of growing weather the dormant eye springs into life, pushed upward with all the accumulated strength of the twoyear root beneath. As soon as this is about 4 inches long we pinch out the end to produce a bushier growth, and this process is repeated several times throughout the month of May or until we consider the plants are bushy enough. We then let Nature have her way.

In addition to the above, the plants for two full summers while in the field must be constantly cultivated and hoed and be protected during the one winter (following the budding) that they are left outdoors. Moreover, during the last summer they must be frequently sprayed or dusted.

From the foregoing it will readily be seen that it must cost something to care for a Rose during its three years of nursery life. As a matter of fact, with rose wages averaging fully two and a half times greater than ten years ago, good Roses at 90 cents to \$I .Oo are today cheaper than at 50 cents then. Greater volume, improved systems, and economies in other directions enable us to sell at these prices. 


\section{Special Hybrid Tea Collection}

To those who want but a dozen Roses in many of the new varieties, we offer the following if taken just as listed. The collection includes those new varieties, in a wide range of most interesting colors, that have been thoroughly tested and are here to stay.

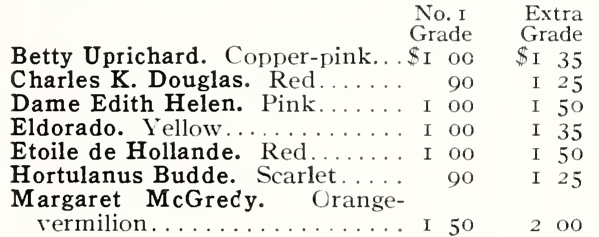

\begin{tabular}{|c|c|c|c|}
\hline & & $\begin{array}{l}0 . \text { I } \\
\text { ade }\end{array}$ & \\
\hline Mrs. Charles Bell. Pink... & & & $\$ I$ \\
\hline Mrs. Henry Morse. Pink. & & 90 & I \\
\hline Padre. Coppery scarlet ....... & & 90 & I \\
\hline $\begin{array}{l}\text { Rev. F. Page-Roberts. Yellow } \\
\text { Souv. de George Beckwith. Sal }\end{array}$ & . I & 50 & 2 \\
\hline & . I & 00 & I \\
\hline & \$I 2 & $5^{0}$ & $\$ 17$ \\
\hline & $\$ 10$ & $\begin{array}{l}00 \\
00\end{array}$ & $\begin{array}{l}\$ 15 \\
\$ 13\end{array}$ \\
\hline
\end{tabular}

The Collection for $\ldots \ldots$
Less an additional 10 per cent for fall

$\$ 900 \quad \$ 13 \quad 50$

The 10 per cent discount will NOT apply in spring.

\section{Standard Hybrid Tea Collection TWENTY OLD FAVORITES}

Here is a collection of "Old Timers" whose names are familiar everywhere in the Rose world. Because of their fine performance over a long period of years, they will always be Peterson favorites.

Grade Grade

Duchess of Wellington. Yellow. . \$I oo \$I 35

Etoile de France. Red........... 90 I 25

Grange Colombe. Cream-yellow. 90 I IO

Gruss an Teplitz. Red.......... 90 I Io

Killarney Queen. Pink........ 90 I Io

Lady Alice Stanley. Pink....... $90 \quad$ I 25

Lady Ashtown. Pink........... 90 I IO

Lady Pirrie. Yellow............ 90 I Io

Laurent Carle. Red........... 90 I IO

Mme. Butterfly. Yellow-pink... 9o I Io

Mme. Caroline Testout. Pink... 90 I Io

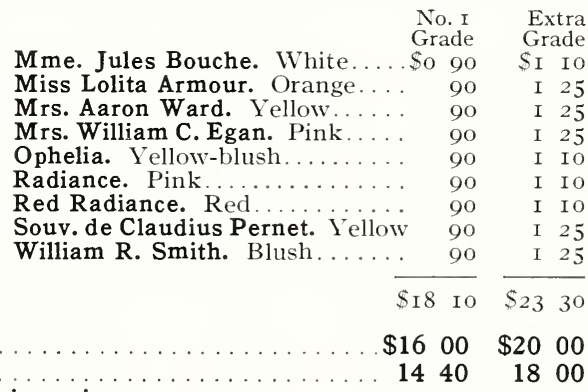

The Collection for $\ldots \ldots$ per cent for fall.

The 10 per cent discount will NOT apply in spring.

\section{The Hybrid Perpetual Dozen}

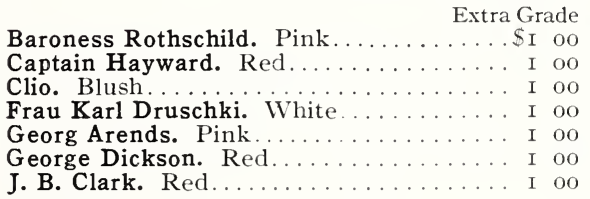

Mrs. John Laing. Pink Extra Grade

Paul Neyron. Pink................. I

Prince Camille de Rohan. Red .......... I oo

Suzanne-Marie Rodocanachi. Pink...... I 00

Ulrich Brunner. Red................. I

$\$ 1200$

The Collection for

Less an additional 10 per cent for fall

The 10 per cent discount will NOT apply in spring. 


\section{The Sizes We Offer and Planting Suggestions}

Our older customers understand what we mean by Extra Grade and No. I Grade stock. For the benefit of new customers, we want to explain that Extra Grade plants are those that have the most number of heavy canes. They will naturally produce a greater crop of flowers the first year and become more quickly established than our No. I Grade. Both sizes are desirable for either fall or spring planting but, as with any other article of merchandise, we find there are those who prefer to buy the best that is obtainable at a slight additional cost.

We are always pleased to assist with the selection of varieties whenever a new Rose garden is being planned. It is an excellent idea to send us a rough diagram showing the proposed dimensions of the beds or else the space you have available, and we can then prepare a planting list (not a plan) that we feel sure will give you a very harmonious arrangement of plants, both as to size and color. This assistance we are pleased to give to private home planters as well as to Landscape Architects.

The small Rose garden, consisting of a dozen or two of Roses, is very easily planned, but even in such a case we believe that the mistake is too of ten made of planting too many different varieties in the same bed. We would much rather see only a few varieties planted in lots of three or four than to see a long list of varieties in single plants. For the beginner, however, and one who wants to learn about Roses, a dozen such as we offer in our Hybrid Tea Set, all of them in different varieties, will furnish you with an idea of just which will be your favorites and which ones will do best in your certain locality. Certainly if we found that some varieties did much better than others, those are the ones we would order in quantity when our next purchase is made.

\section{Prices for This Fall and Next Spring}

A discount of 10 per cent will be allowed on all Roses shipped this fall. This discount is given in addition to the quantity rates as below listed and brings our prices to the same level that they have been the last two years.

\section{Regular Listed Prices Will Prevail for Spring, 1930}

This is a very reasonable and logical method of pricing Roses because it is becoming more and more expensive to properly handle and store Roses over the winter. Evidence of this is shown in the custom of the trade to advance wholesale prices in spring above those in fall. The fall discount is made not necessarily to sell more Roses at that time of the year, but to pass on to our patrons the saving it means to us to ship Roses directly after digging and harvesting, thus eliminating the extra handling charges in storage.

\section{Quantity Prices of Roses}

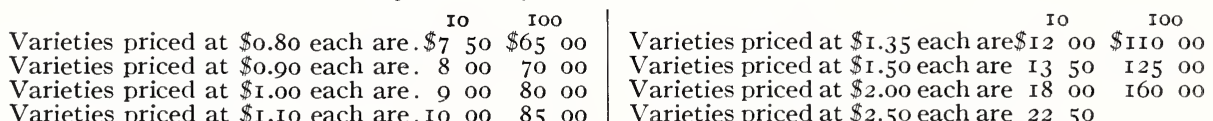
Varieties priced at $\$$ I.Io each are. Io oo 85 oo $\quad$ Varieties priced at $\$ 2.50$ each are 2250

Varieties priced at $\$$ I.25 each are. I I oo Ioo oo

In order to obtain the 10-rate, order 10 or more Roses in lots of 3 or more of each variety (not class) wanted.

EXAMPLE: If you order, say, 3 Clio, 3 Paul Neyron, 3 Columbia, 3 Ophelia, and 1 Radiance, you will be entitled to the 10-rate on all but Radiance.

In order to obtain the Ioo-rate, order 50 or more Roses in lots of Io or more of each variety wanted.

\section{FALL PLANTING INSURANCE PLAN}

By adding 10 cents to the cost of each plant, we will insure you against any and all losses over the first winter and up until June 1, 1930. This marks the third year that we have introduced this plan and it is working out very successfully. It is especially meant for those who have some doubts about the degree of safety with which they may plant Roses this fall. The 10 per cent discount we are allowing this fall practically insures all fall-planted stock free of charge.

This insurance plan does not apply to spring-planted stock but any reasonable complaints due to losses from spring planting will be duly considered and fully adjusted. See last page of order sheet. 


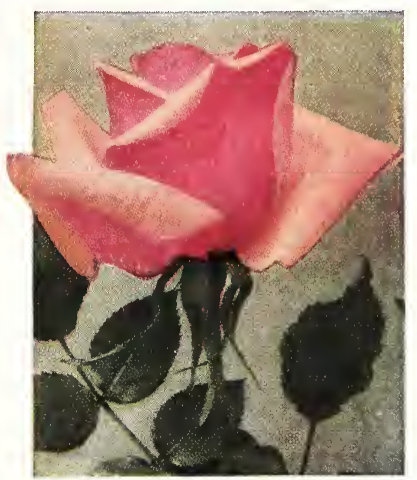

Betty Uprichard

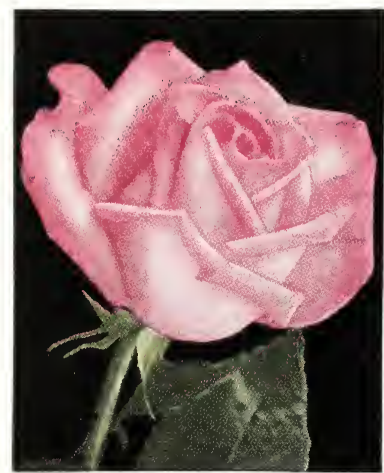

Columbia. See page 8

\section{Hybrid Tea Roses}

(Everblooming)

Prior to fifteen or twenty years ago, the Hybrid Perpetual or Remontant class of Roses was the chief one. During the past twenty-five years, the development of the Hybrid Tea class has been very rapid, so that now they are considered the leading class of Roses.

The varieties of this class were originated, as the name implies, by intermingling the blood of the Tea Rose with that of another class, usually the Hybrid Perpetual. By this method, a Rose is produced combining the constant blooming qualities of the former with, to a certain extent, the vigor of growth and hardiness of the latter.

Most of the varieties are noted for their continuous blooming qualities throughout the growing season from June to October. The range of color is nothing short of phenomenal, especially if one includes the noteworthy varieties introduced within the last five years which give to us such unique colorings in the yellow and copper shades. Quite a few of these we offer this year for the first time.

ANGELE PERNET. Moderate. Pernet-Ducher, I924. A comparatively new Rose, very distinct color-a bright brownish orange changing to a bronzed yellow when fully open. Flower is cup-shaped and nearly single. We have not seen anything else like it and hope the constitution of the plant is such that it will succeed. Plant of only moderate growth and appears to be a bit delicate; one for the advanced amateur. The first year we have offered it. No. 1 Grade, $\$ 1.25$; Extra Grade, $\$ 1.50$.

BETTY. Vigorous. A Dickson \& Sons, I905. Very large, pointed bud, opening quickly to a semi-full flower; in color described by the originators as "a ruddy gold and coppery rose overspread with golden yellow." In bud this is exquisite. Best in autumn. Makes breaks at the base, noted for their strength and rapidity of growth, which are of a beautiful garnet-red, lined with bright red thorns. One of our old pets that is doing better every year. No. 1 Grade, 90 cts.; Extra Grade, \$1.25.

BETTY UPRICHARD. Very vigorous. A Dickson \& Sons, I920. The flowers are semidouble, large, charmingly ruffled, and present an almost startling contrast in coloring. The outside of the petals is fiery copper-pink, and the inner surface is soft salmon. In the bud stage this contrast is extremely vivid, but the open flower shows little of it except when viewed from the back. The growth and blooming qualities of the plants are exceptionally good, and in every way this can be considered a very superior variety. No. 1 Grade, \$1.00; Extra Grade, \$1.35. See illustration above. 


\section{HYBRID TEA ROSES, continued}

CHARLES K. DOUGLAS. Very vigorous. Hugh Dickson, I9I9. A splendid bright red garden Rose of rather informal shape, quite large, and moderately fragrant. This high-grade Rose has been overlooked by almost everybody, which is strange because good reds with anything like its vigor and floriferousness are extremely scarce. Flowers not quite so bright nor as shapely as Etoile de Hollande, but with us it is the best continuous red bloomer, especially during hot summer months. No. 1 Grade, 90 cts.; Extra Grade, \$1.25. See illustration on page I4.

ChateAU DE ClOS VOUGeOT. Moderate. Pernet-Ducher, 1908. This is an old variety we have not offered for several years but again we find it in demand. The color shades from the richest glowing blood-red to almost black, with a velvet-like finish. Color is at its richest in September. Delightfully fragrant. Plant is only moderate grower; very low and spreading. No. 1 Grade, 90 cts.; Extra Grade, $\$ 1.25$.

COLUMBIA. Vigorous. E. G. Hill, I9I8. Both as a forcing Rose and for outdoor planting, this has been one of the most popular Roses during the past ten years or so. The flower is very full, moderately large, and comes on nice long, stiff, upright stems with very few thorns. In color it is a bright, lively pink, best in shade, as most Roses are, in the autumn. It is best, too, generally at that season since during the summer it does not always develop perfectly. In the matter of fragrance, it is superlatively good and all in all makes a splendid cut-flower.

The new variety Briarcliff is a sport of Columbia, but until we know more about it we shall stick to Columbia. No. 1 Grade, 90 cts.; Extra Grade, \$1.25. See illustration on page 7.

CUBA. Moderate. Pernet-Ducher, 1927. A new variety, somewhat similar to Padre. The very bright orange-scarlet buds open to form a big single cup-shaped Rose. In this respect it has fewer petals than Padre. A Rose for the connoisseur and we do not guarantee its hardiness under northern climatic conditions. New with us. A rather dainty and refreshing new Rose which we wish to learn more about. No. 1 Grade, \$1.00; Extra Grade, \$1.50.

DAME EDITH HELEN. Very vigorous. A. Dickson \& Sons, 1926. A large finely shaped, clear pink bloom with plenty of substance, produced on long, stiff stems; very sweet scented; foliage free from mildew and black-spot. While not any too generous with its flowers during midsummer, the crop of truly perfect pink flowers it gives us both during early summer and early fall again is even more than we ask for in a new variety. Flowers when fully opened, while enormol's in size, remain perfectly built with every petal gracefully tapered to a curled point. No. 1 Grade, \$1.00; Extra Grade, \$1.50. See illustrations on pages 9 and II.

DUCHESS OF WELLINGTON. Vigorous. A. Dickson \& Sons, 1909. Intense saffronyellow, changing to orange-coppery-yellow. Flower large to very large, moderately full. Long, pointed buds; good grower. Long one of the most popular of all yellow Roses. At its best in autumn. No. I Grade, \$1.00; Extra Grade, \$1.35. See illustration on page I I.

EDEL. Vigorous. S. McGredy \& Son, I9I9. This variety combines strength of growth with high quality of flower to a greater degree than found in any other white everblooming Rose. The bloom opens a creamy ir ory-white fading to pure white. The flower is large, very full, symmetrically formed, camellia-like in appearance and bids fair to take its place as the best all-round white Hybrid Tea Rose yet produced. No. 1 Grade, 90 cts.; Extra Grade, \$1.25.

ELDORADO. Very vigorous. Howard \& Smith, 1922. In our opinion this variety stands out preëminently among the yellow everblooming Roses. To begin with, the growth is strong and upright, very similar to that of its first cousin, Miss Lolita Armour. The flower, one of the clearest of yellows, is very large and full, reminding one of that old-time famous Climbing Rose, Marechal Niel. We rather prefer this variety to Souv. de Claudius Pernet because the early blooms of the latter often come "dirty" especially in June when Eldorado is invariably perfect. With us it is a very disease-resisting variety and has excellent foliage. The flower is fuller and has more substance than the newer true yellow, Ville de Paris. And even though Eldorado is sometimes a little too large for the stem that carries it, causing it to nod a bit, we still prefer it to any of the newer pure yellows. No. 1 Grade, \$1.00; Extra Grade, \$1.35. See illustration on page 10. 


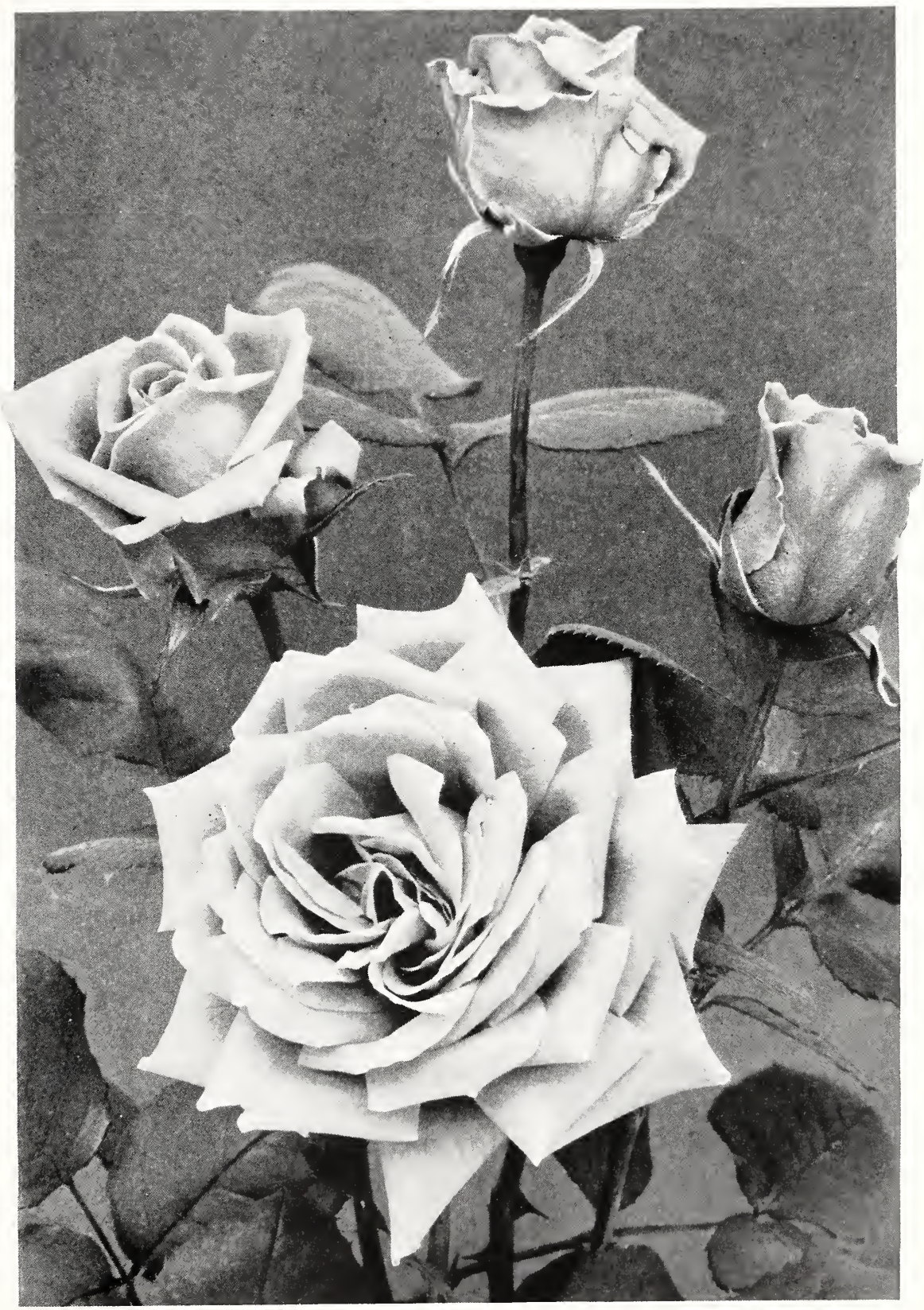

Dame Edith Helen. See page 8 


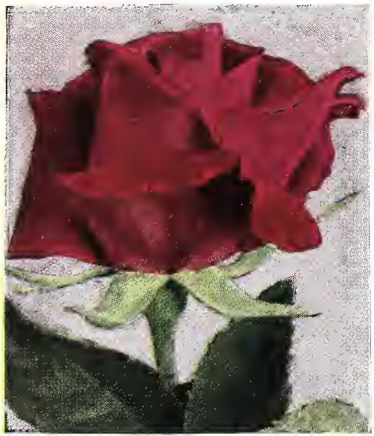

Etoile de Hollande

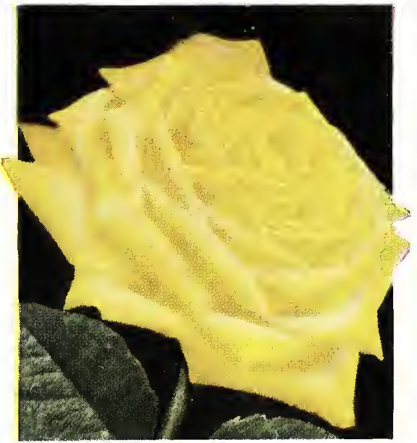

Eldorado. See page 8

\section{HYBRID TEA ROSES, continued}

ETOILE DE FEU. Moderate. Pernet-Ducher, I92I. A moderately large, full flower of a striking shade of orange-pink, somewhat similar to the old Louise Catherine Breslau. Foliage glossy and seems to be quite disease-resisting; the plant spreading and bushy. Very distinct among the new flame-colored Roses. No. 1 Grade, \$1.00; Extra Grade, \$1.35.

ETOILE DE FRANCE. Vigorous. Pernet-Ducher, I904. Rich, glowing, velvety crimson centering to vivid cerise; large and very full; most deliciously fragrant. Flowers come singly on long, strong stems, making it invaluable for cutting. One of the best and most popular of the everblooming reds. No. 1 Grade, 90 cts.; Extra Grade, \$1.25.

ETOILE DE HOLLANDE. Vigorous. H. A. Verschuren \& Sons, I9I9. This is one of the very best of recent introductions among red everblooming Roses. To begin with, the growth is good and the color of the bloom is a very deep, rich, glowing red one. The flower, moderately full, is not densely packed with petals such as we find in Francis Scott Key and consequently it does not produce, as does this variety, more or less balled, undeveloped flowers, particularly in a wet spell. Last year we said this variety promised to do well with us; this year we are quite sure it has more than come up to our expectations in giving us such a really good everblooming, red Rose, of which we have none too many. The foliage is quite disease-resisting and our plants, even during the hot, damp days of early August are just a mass of flowers and foliage. No. 1 Grade, \$1.00; Extra Grade, \$1.50. See illustration.

FEU JOSEPH LOOYMANS. Vigorous. P. J. Looymans \& Sons, 1922. A handsome goldorange Rose especially attractive in its massive buds and splendid pointed flowers. It has the habit of producing divided or split blooms early in the season, or when newly planted, but this disagreeable trait disappears as the season advances. It gives us the longest and most distinctive buds of all our newer yellow varieties. A splendid new Rose. No. 1 Grade, \$1.00; Extra Grade, \$1.35.

FRANCIS SCOTT KEY. Vigorous. John Cook, I9I4. This is the largest of all the red Hybrid Tea Roses. It is also one of the fullest and most symmetrically formed. The growth, too, is very good, strong and upright. The flower is a rather peculiar and unusual shade of red. We know of no better way to popularly convey the shade of this than to term it a brick-red combined with royal-purple. It is also very rich in fragrance. In the summer it has a tendency to purple and "ball" but in the fall it is a truly wonderful Rose. No. 1 Grade, 90 cts.; Extra Grade, \$1.25.

GENERAL MacARTHUR. Vigorous. E. G. Hill, 1905. Brilliant, scarlet-red; both moderately large and full; fragrant. Good habit and bloomer. In reds we have not as yet attained the perfect Rose and, while this variety is a good, bushy grower and good, reliable bloomer, the flowers during the heat of midsummer are notably weak in color. One must not, however, expect to find, in the average United States climate, any Roses at their best during hot, dry weather. No. 1 Grade, 90 cts.; Extra Grade, \$1.10. 


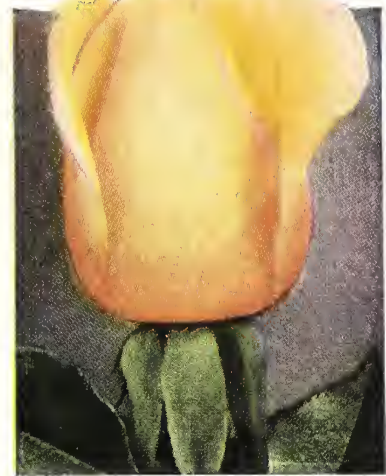

Duchess of Wellington. See page 8

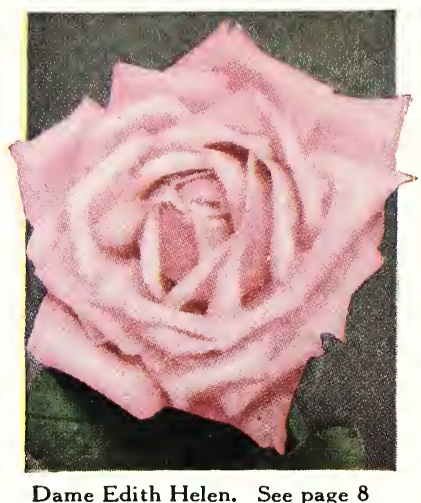

Dame Edith Helen. See page 8

\section{HYBRID TEA ROSES, continued}

GRANGE COLOMBE. Vigorous. P. Guillot, I9I2. Large to very large and full flower of good form; creamy white, shaded yellow. Growth strong, and plant of good, erect habit. To anyone looking for a yellowish white Rose of very large size, we can warmly commend this variety. Also an old favorite of ours because it invariably produces a strong plant and many flowers throughout the season. Perhaps its name has checked its popularity, but we shall continue to grow it nevertheless. No. 1 Grade, 90 cts.; Extra Grade, \$1.10.

GRUSS AN TEPLITZ. Very vigorous. Geschwindt, I 897 . Velvety crimson, shading to scarlet center. An exceedingly strong grower, with beautiful, plum-colored foliage. Cup shaped, moderately full flowers, usually coming in small clusters at the end of long stems. Very fragrant. A very free and continuous bloomer. Its absolute hardiness, beautiful foliage, and its very free and continuous blooming qualities, make this the greatest Rose for massing and hedging we possess. A Rose which the merest tyro cannot help but succeed with, growing where most Roses would fail. Because of its abnormally strong, bushy growth, we do not recommend that it be planted in beds with other Hybrid Teas. It will bloom best in moderately good to poor soil and it should not be pruned severely as most other Roses should be. It will make splendid single or group specimens and is one of the very best of all for ornamental hedge purposes where a strong growth of 4 to 6 feet high is desired. No. 1 Grade, 90 cts.; Extra Grade, $\$ 1.10$.

HAWLMARK CRIMSON. Vigorous. A. Dickson \& Sons, 1920. This is one of the richest, dark red Roses yet introduced. The buds are crimson with bright maroon markings, opening to crimson scarlet. The flower is semi-double. This variety and Hortulanus Budde, which is a brighter red, are at present our two best red bedding Roses, of vigorous, bushy habit. The buds, moreover, are exquisite and come on stems sufficiently long for cutting. No. 1 Grade, 90 cts.; Extra Grade, \$1.25.

HORTULANUS BUDDE. Vigorous. H. A. Verschuren \& Sons, I9I9. The plant with us is a good, bushy grower, more or less spreading and produces a medium large and medium full flower of a deep scarlet-red which is very glowing. Very liberal with its flowers, it makes an excellent bedding Rose where vivid color is wanted. Also good for cutting in the bud stage. We hope its peculiar name will not be a hindrance to a more deserved popularity. No. 1 Grade, 90 cts.; Extra Grade, \$1.25.

IMPERIAL POTENTATE. Vigorous. Clarke Bros., I923. This is an exceedingly large, full, rich, rose-pink flower which invariably opens perfectly and of good form. This comes to us from the Pacific Northwest where its advent was loudly heralded. It is bearing out with us the high reputation given it. Sweetly scented and very free flowering. No. 1 Grade, 90 cts.; Extra Grade, \$1.25. 


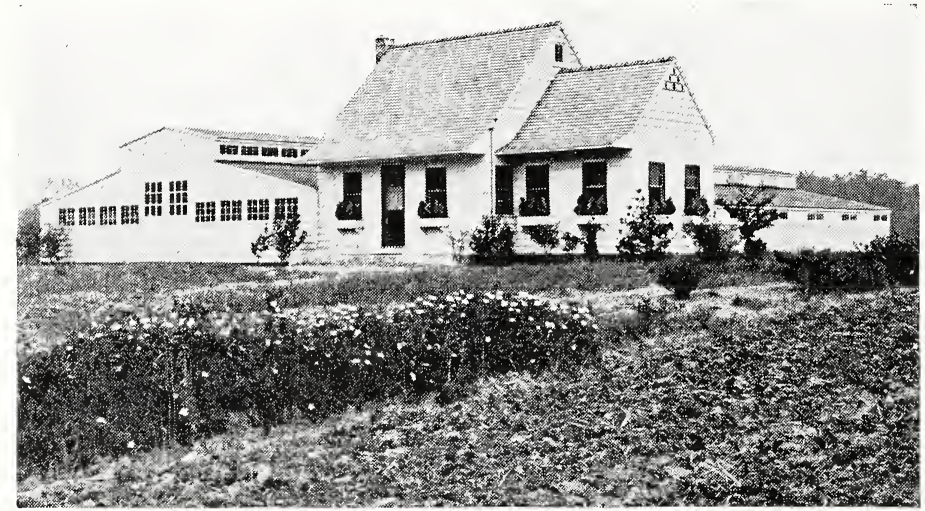

Our New Office, Packing and Storage Sheds

HYBRID TEA ROSES, continued

INDEPENDENCE DAY. Vigorous. Bees Ltd., I919. Flower moderately large and moderately full but borne most prolifically throughout the entire growing season. The color is very striking, being a combination of orange, copper and pink. Splendid as a decorative bedding Rose. We have finally succeeded in working up a good stock of this variety; always in demand. No. 1 Grade, 90 cts.; Extra Grade, \$1.25.

JONKHEER J. L. MOCK. Vigorous. M. Leenders \& Co., I9Io. Large to very large, full flower; long, pointed bud on long, stout stem. Outside of petals brilliant carmine-rose; inner side silvery, rosy white. Very erect, strong grower, with splendid stems for cutting. Wood almost thornless. The large size of its blooms, together with its two-colored petals, cause many to think it artificial when used as a cut-flower. Will sometimes "ball." Is usually at its best in autumn. No. 1 Grade, 90 cts.; Extra Grade, \$1.10.

KAISERIN AUGUSTE VIKTORIA. Moderate. Lambert and Reiter, I 89I. Creamy white, faintly tinged with lemon; large and full. An exquisite flower, possessing much style and a distinct magnolia-like fragrance. Fine, glossy foliage. A royal Rose, exceedingly chaste and very popular, but unfortunately, it is lacking in that vigor of growth which is desirable in a variety for the average planter. Old as it is from a Hybrid Tea standpoint, no white of later introduction can compare with it for quality of bloom. No. 1 Grade, 90 cts.; Extra Grade, \$1.25.

KILLARNEY QUEEN. Vigorous. Budlong \& Son Co., I9I2. This is a sport from the original Killarney, and is identical with that variety in form of flower, but the color is much deeper and richer than in the parent. The flower is also decidedly larger, and the plant is a much more vigorous grower than either Killarney or Killarney Brilliant. The latter variety we have discarded, as we consider Killarney Queen much superior in every respect. Of the many Killarney sports that have teen produced, this easily holds first place. No. 1 Grade, $90 \mathrm{cts}$.; Extra Grade, \$1.10. See illustration on page $3 \mathrm{I}$.

LADY ALICE STANLEY. Vigorous. S. McGredy \& Son, I909. A Rose of more than ordinary vigor and size of flower. Outside of petals deep coral-rose; inside pale flesh. In this variety we have a most delightful sort; fragrant, and coming on good, stiff stems for cutting. McGredy's productions are, as a rule, of great merit and this variety is no exception. No. 1 Grade, 90 cts.; Extra Grade, $\$ 1.25$.

LADY ASHTOWN. Vigorous. A. Dickson \& Sons, 1904. As many of our old customers will readily recall, this variety has long been a favorite of ours. It is one of the so-called old Hybrid Teas and it has come through many years of trial without failing in a single respect.

In the matter of growth it is fully up to the average good Hybrid Tea. This refers to both strength and bushiness. In matter of number of blooms, it stands above the average and the 


\section{HYBRID TEA ROSES, continued}

quality of the flower is very close to the top. The buds are more or less pointed and exquisitely formed. In color it is a medium shade of self-pink, i. e., one solid shade. Flower opens perfectly to a very full bloom and we can recommend it to the beginner as well as the experienced planter as a variety which will not disappoint. No. 1 Grade, 90 cts.; Extra Grade, \$1.10. See illustration on page I4.

LADY PIRRIE. Vigorous. Hugh Dickson, igIo. Here we have an unusually rich and attractive bud described by the introducer as "deep coppery reddish salmon; inside of petal apricot-yellow, flushed fawn and copper." This is a really lovely variety, coming on nice, long, upright stems, and set off with distinct and beautiful foliage. Exquisite for cutting in bud stage. Plants exceedingly fine this year. No. 1 Grade, 90 cts.; Extra Grade, \$1.10. See illustration on page $3 \mathrm{I}$.

LADY URSULA. Very vigorous. A. Dickson \& Sons, I908. In this variety we have what we believe to be the strongest-growing Rose of all the pure Hybrid Teas. The flower is of good form and size, full, and in color is flesh-pink, much like the famous climber Dr. W. Van Fleet. The plant not only grows vigorously and high, but is of bushy growth as well, producing its flowers very abundantly, especially in the fall when it is usually at its best. We would especially recommend a trial of this Rose to those who desire strong, high-growing varieties in the Hybrid Tea class which require no coddling. No. 1 Grade, 90 cts.; Extra Grade, \$1.10.

LA FRANCE. Vigorous. Guillot, i 867. Delicate silvery rose; large, full and of fine, globular form. Exceedingly fragrant, with a sweetness peculiar to itself. Very hardy and free-blooming. A Rose rarely requiring an introduction, as it is, next to General Jacqueminot, probably the best-known Rose in existence. Owing to its very dense petalage, the buds of this variety will become "balled" under excessive moisture. It will also of ten develop more perfectly in an open, gravelly soil than in a rich, dense one. One of the first Hybrid Teas introduced, it still has a remarkable hold on the rose-lover, due, probably, to its incomparably delicious fragrance and its ability to withstand both neglect and trying weather conditions. No. 1 Grade, 90 cts.; Extra Grade, \$1.10.

LAURENT CARLE. Vigorous. Pernet-Ducher, I907. Carmine-crimson; very large to immense in size; moderately full. Strong grower; good, persistent bloomer and one of the most delightfully fragrant of all Roses. Its splendid buds come on long stems, making it ideal for cutting. Exceptionally hardy for a Hybrid Tea. An excellent red variety which we shall always be enthusiastic about. No. 1 Grade, 90 cts.; Extra Grade, \$1.10. See illustration on page 27.

LOS ANGELES. Vigorous. Howard \& Smith, I9I 7. This is now one of the best known and most admired of Everblooming Roses and is a thoroughbred American, having been born here. The flower is very large and full, with buds of exquisite form, the general effect being a rich salmony pink with yellow at the base of the petals. Possessing as it does more or less Pernetiana blood, it has, where unsprayed, the tendency to lose its foliage more or less during the summer, but by using "Pomodust," referred to in detail in the cultural pages of this book under the head of "Diseases and Insects," this trouble can be prevented. Always in great demand, in spite of the fact that it gives us trouble the second year here in the East. Many of you may in your travels have noted how remarkably well it does on the Pacific Coast. No. 1 Grade, 90 cts.; Extra Grade, \$1.25.

MME. BARDOU JOB. Vigorous. Dubreuil, I9I4. Handicapped, to begin with, with an unattractive name, this desirable yellow Rose has quite a little to live down. With us year after year, it has proved a very desirable yellow, the color of which is a clear sulphur-yellow, fading to white at the edges of petals. With us, too, the color invariably holds up better throughout the summer than in almost any other yellow Rose. Growth is moderately strong, spreading, and bushy. Always in bloom during the heat of August when especially some varieties are shy bloomers. No. 1 Grade, 90 cts.; Extra Grade, \$1.10.

MME. BUTTERFLY. Vigorous. E. G. Hill, I9I8. This is a sport from the well-known Ophelia and in growth, habit, and style of flower is identical with that variety. Mme. Butterfly has often been termed "a glorified Ophelia." There is more pink and life to the flower than is found in the one from which it sprang. No. 1 Grade, 90 cts.; Extra Grade, \$1.10. 


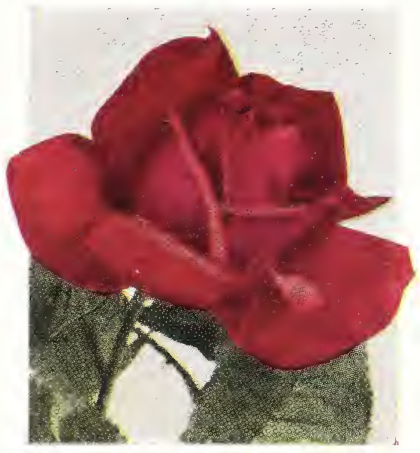

Charles K. Douglas. See page 8

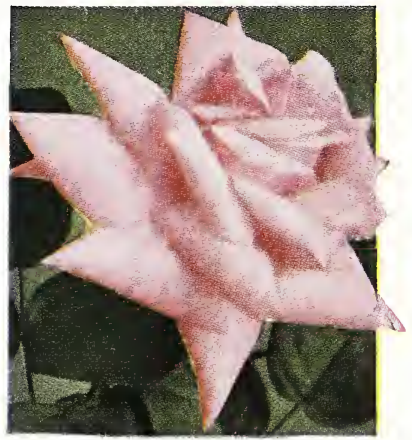

Lady Ashtown. See page 12

\section{HYBRID TEA ROSES, continued}

MME. CAROLINE TESTOUT. Vigorous. Pernet-Ducher, I89o. Light salmon-pink; very large and perfect flowers of globular form, seldom coming malformed. This is one of the oldest and best known of the Hybrid Teas and has long been the show Rose of the Pacific Coast, where it is grown in hedges along the streets. A good, rugged, vigorous grower. No. 1 Grade, 90 cts. ; Extra Grade, \$1.10.

MME. EDOUARD HERRIOT. Moderately vigorous. Pernet-Ducher, I9I3. This Rose is also known as the "Daily Mail." Like others of the Pernetiana class which possess an abundance of yellow brier blood, it will lose its foliage by midsummer if not sprayed or dusted. It is one of the very first Roses to bloom outdoors and the first crop is a profuse one. The flower, too, is so striking in color that attention is at once drawn to it and one beholding it for the first time can hardly command adjectives expressing his admiration. Waiving aside technical terms, it is the richest salmon-pink Rose in existence and is described by the originator as "coral-red, shaded with yellow and bright rosy scarlet with yellow at the base." This variety succeeds over a wide range of latitude. No. 1 Grade, 90 cts.; Extra Grade, \$1.25.

MME. JULES BOUCHE. Very vigorous. J. Croibier \& Fils, I9I I. Very full, pearly white, camellia-like flower, tinged with blush. Growth exceedingly bushy and strong, and a prolific bloomer. This variety is at its best in autumn and if then disbudded, the remaining flowers will be large and often faultless. Has a good record in "coming through" the past few years. Classed by some critics as the best white Hybrid Tea. Invariably stands out in our rows as a strong and free-flowering bush. No. 1 Grade, 90 cts.; Extra Grade, \$1.10.

MARGARET McGREDY. Very vigorous. S. McGredy \& Son. This Rose we have had under observation for four years along with many other of the newer varieties and we are now ready to predict that in time, as stock becomes more plentiful, it will be one of our most widely grown Roses. The color is very difficult to describe: red, rose, and flame on the upper side of the petals, the under surface suffused with gold-a wonderful contrast; perhaps orangevermilion would best describe it. Growth is very vigorous and foliage dark olive green, quite free from mildew and black-spot; bush well shaped, requiring little pruning. The ovoid buds and double cupped blooms are of good substance and depth of petals and are produced on stiff stems, medium in length. Very free and prolific bloomer and extremely hardy most anywhere in the United States. No. 1 Grade, $\$ 1.50$; Extra Grade, $\$ 2.00$. See page 2.

MISS CYNTHIA FORDE. Very vigorous. Hugh Dickson, 1909. Of all the clear, rich pinks, this is one of the very largest, best, and most striking. The flower is very full, the petals beautifully imbricated, and in the fall one often gets flowers from it almost as large as a peony. The growth is remarkably strong and upright, and apparently is a variety which can stand anything which Nature may send in the way of weather. It should certainly be in every collection, large and small. No. 1 Grade, 90 cts.; Extra Grade, \$1.10. 


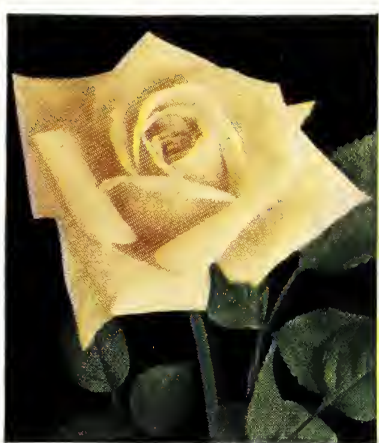

Mrs. Aaron Ward

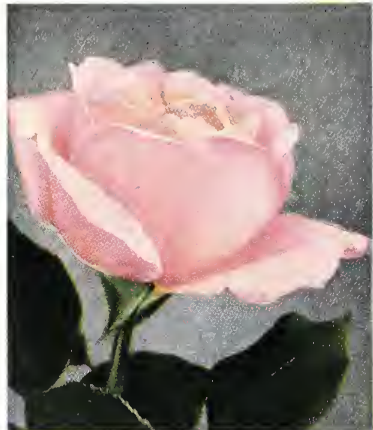

Mrs. Charles Bell

\section{HYBRID TEA ROSES, continued}

MISS LOLITA ARMOUR. Vigorous. Howard \& Smith, I920. Large to enormous, very full flower, opening more or less irregularly as to form. Its chief value lies in its unusual and attractive color, difficult to popularly describe. This is described by the introducer as "a deep coral-red with a golden coppery red suffusion." The growth is very strong and upright and this, too, is of a both unusual and attractive color. No. 1 Grade, 90 cts.; Extra Grade, \$1.25.

MISS WILLMOTT. Vigorous. S. McGredy \& Son, I917. This is the best white or nearly white Hybrid Tea Rose. It is especially prolific in the hottest weather, preserving the same pearly whiteness and dainty cream and pink flushes that it has in the early spring. The blooms are exceptionally well formed. This Rose is distinct from Ellen Willmott. No. 1 Grade, \$1.00; Extra Grade, \$1.35.

MRS. AARON WARD. Moderate. Pernet-Ducher, I907. Indian-yellow, variable in color, edging to white. Flowers medium in size, full, and of perfect cupped form, borne profusely and continuously on rigid, upright stems. Very good foliage. Growth moderately vigorous, but bushy. This is a Rose of unusual individuality and charm and of which we cannot speak too highly - a Rose to love. For table decoration or buttonhole it is simply incomparable. Blooms are often at the beginning of the season quite whitish but the color comes back in the later blooms. No. 1 Grade, 90 cts.; Extra Grade, $\$ 1.25$. See illustration.

MRS. A. R. BARRACLOUGH. Very vigorous. S. McGredy \& Son, I926. Bud very large, long pointed; flower double, high-centered. Bright, soft, sparkling carmine-pink of even shade throughout, shading to yellow at base, becoming brighter with age. Stems long and strong. Good profuse bloomer. A new Rose; the first year we have offered it. It is doing well in the fields but we know little about its subsequent behavior in gardens. No. 1 Grade, \$1.50; Extra Grade, $\$ 2.00$.

MRS. CHARLES BELL. Vigorous. Mrs. Charles Bell, I917. This is the third of the Radiance Roses. In growth and form of bloom it is of the true Radiance type but the color is very distinct. It is, in fact, one of the most delicate, refined, light salmon-pink shades found in Roses. We see no reason why, in a very few years, it should not rival both Radiance and Red Radiance in popularity. No. 1 Grade, 90 cts.; Extra Grade, \$1.25. See illustration.

MRS. ERSKINE PEMBROKE THOM. Vigorous. Howard \& Smith, 1926. A new showy yellow garden Rose. The deep yellow buds with carmine markings open to semi-double bright yellow flowers. This variety appeals to us because the bush is unusually strong, stocky, and robust. Perhaps not so good for cut-flowers because of the short stems but where one wants masses of yellow in the Rose garden, we believe Mrs. E. P. Thom, with its very attractive foliage as well as flowers, will soon become very popular. No. 1 Grade, \$1.50; Extra Grade, \$2.00.

Preserve this booklet for future reference. The text matter in the last part will assist you in growing better Roses 


\section{HYBRID TEA ROSES, continued}

MRS. FRANKLIN DENNISON. Very vigorous. S. McGredy \& Son, I9I5. An enormous globular, very full, blush-white flower, somewhat suggestive of the old Florence Pemberton. The growth is unusually strong for a Hybrid Tea, quite rugged, in fact, in character, and all in all it seems to have displaced such varieties as Souv. du President Carnot and Pharisaer. No. 1 Grade, 90 cts.; Extra Grade, \$1.10.

MRS. HENRY BOWLES. Very vigorous. Chaplin Bros., I92I. Here we have a new true pink variety showing much promise. Splendidly shaped buds of a rich, clear pink open into a very well-built and firm flower, the petals of which have much substance. A good free bloomer; noticeably fragrant; bush very strong and vigorous. We like it better than Mrs. A. R. Barraclough and believe that in spite of all our many pink Roses, Mrs. Henry Bowles will soon take its place at the front. No. 1 Grade, \$1.50; Extra Grade, \$2.00.

MRS. HENRY MORSE. Very vigorous. S. McGredy \& Son, I9I 9. In all around flowering habits, this Rose is performing better for us year after year. Upon first noting the great mass of bloom in the nursery row, one would expect upon closer examination not to find such a particularly well-formed flower, but we assure you that in all stages of development of this flower from the time the bud first appears until almost the last petal is ready to fall, it possesses an unusually beautiful form and color. The petals are colored somewhat similar to Radiance; i. e., the outside of the petal is more or less a deep rose and the inside a soft flesh-cream. The growth is exceptionally good and strong and bushy and all in all this variety stands close to the top among pink everblooming Roses. It may not be necessary to include the originator's description, but it follows just the same: "Rising from a groundwork of soft flesh-cream, the whole flower has a clear sheen of bright rose, deeply impregnated and washed vermilion, with clear vermilion veining on the petals which are really wonderful for depth, size, and substance. Sweetly scented." No. 1 Grade, 90 cts.; Extra Grade, \$1.25. See illustration on page I8.

MRS. WILLIAM C. EGAN. Very vigorous. Howard \& Smith, I922. Judging by the demand, few Roses jump so quickly into popular favor as this one has. It is one of our best Roses of recent American origin. The buds are long and beautifully pointed and develop to an exceedingly large, full flower, perfect in every stage. The color is two-toned, i. e., one side is decidedly pink and the reverse side flesh, the whole effect being soft flesh-pink with a yellowish tinge at the base of the petals. Our stock this year is particularly fine and we expect for the first time to have sufficient extra grade plants to go around. No. 1 Grade, 90 cts.; Extra Grade, $\$ 1.25$.

OPHELIA. Vigorous. Wm. Paul \& Son, I9I2. This variety rapidly jumped to the front as one of the most popular of Hybrid Teas, and as a cut-flower for winter forcing it stands preëminent. As an outdoor Rose also it has proven of unusual worth. The growth is exceedingly good and habit fine and upright. The flowers are of splendid form, full, and yet not too densely packed with petals; as a result, practically every flower opens perfectly. The color is sometimes variable and not easy to popularly describe. In it we find salmon, flesh, pink and yellow, a combination which gives us a most refreshing tone. One of the most popular Hybrid Tea Roses. No. 1 Grade, 90 cts.; Extra Grade, \$1.10.

PADRE. Vigorous. B. R. Cant \& Sons, I $92 \mathrm{I}$. For the past three years this Rose has been an outstanding variety in our fields beyond almost any other. Its unique flame color-a coppery scarlet, flushed with yellow at the base of the petals-makes it one of the most distinctive Roses so far as color is concerned that we have offered in many years. Growth, while not stout, is tall and upright and of sufficient strength to maintain that position throughout the season. The buds come on long to very long stems and make a most attractive cut-flower while in the bud stage. The flower itself on opening is moderately large though not so full. Of all the newer Roses, this is one which the Rose fancier must add to his collection. No. 1 Grade, 90 cts.; Extra Grade, \$1.10. See illustration on page I 8.

QUEEN OF FRAGRANCE. Vigorous. W. Paul \& Son, I9I5. As implied by its name, this is a Rose very highly and sweetly perfumed. It is also strong in practically all other characteristics which are desired in a Rose. It is, to begin with, a strong, upright grower and yields profusely its very large, full, bright shell-pink flowers. Its foliage is also notably beautiful. No. 1 Grade, 90 cts.; Extra Grade, \$1.10. 


\section{HYBRID TEA ROSES, continued}

RADIANCE. Very vigorous. John Cook, I908. In this variety we have an exceptionally strong, upright, vigorous grower, bearing profusely a very large, globular-shaped flower of a nice even shade of pink. In the autumn this variety easily stands out because of its height and profusion of bloom from all other surrounding varieties. Splendid for both cutting and garden decoration and one of the most generally successful Hybrid Tea Roses the entire country over. No. 1 Grade, 90 cts.; Extra Grade, \$1.10. See illustration on page 27.

RED RADIANCE. Very vigorous. Gude Bros., I9I6. This is a sport from the famous. Radiance but, as its name implies, is red in color but not of a deep shade. It has all the characteristics of its parent, Radiance, in the way of growth, blooming qualities, and form of flower and is now practically as well known as its pink relative. No. 1 Grade, 90 cts.; Extra Grade, $\$ 1.10$. See illustration on page 30 .

RED STAR. Vigorous. H. A. Verschuren \& Sons, I9I8. A very large semi-full flower of big petalage and of a dazzling shade of red. The growth is good and the flowers are borne quite freely. It is splendid as a bedding or decorative variety. No. 1 Grade, 90 cts.; Extra Grade, $\$ 1.10$.

REV. F. PAGE-ROBERTS. Vigorous. B. R. Cant \& Sons, I92 I. This is one of the richest, fullest and most perfect yellow Roses yet produced. The bud is beautifully marked and marbled with carmine-red. The bloom is a very full one and of great substance, and comes on a stocky plant, well branching, but of moderate height. It is a variety we predict will be in short supply for quite a few years to come, not only because of the great demand for it, but because it is rather a slow and difficult one to propagate. Surely it is a variety which the Rose connoisseur must have. See illustration on page I9.

We have decided not to offer the newer variety, Lady Margaret Stewart, which closely resembles Rev. F. Page-Roberts, until another year. It is a variety that we have propagated but wish to learn more about before offering it for sale. No. 1 Grade, \$1.50; Extra Grade, \$2.00.

SOUV. DE CLAUDIUS PERNET. Vigorous. Pernet-Ducher, I920. Ve doubt if any Rose of comparatively recent introduction has been so widely advertised and so much talked of as this variety. It has taken a wonderful hold on the buying public and we are sure that more plants of it have been sold within the past few years than of any other yellow Rose. The growth is very sturdy and upright with glossy, healthy foliage. In color it is one of the clearest and most lasting of yellows. Its chief fault lies in its tendency, especially in the early season, to show a "dirty" center when the flower is fully opened. It improves in this respect as the season progresses and this one drawback does not prevent it from being planted more largely than any other yellow Rose of our day. No. 1 Grade, 90 cts.; Extra Grade, \$1.25. See illustration on page 30 .

SOUV. DE GEORGE BECKWITH. Very vigorous. Pernet-Ducher, I9I9. The flower of this on first opening suggests very much the old Lyon Rose and the present-day Los Angeles, i. e., the color is a combination of a salmon-pink-yellow, though somewhat lighter in tone than found in Los Angeles. The color is, however, less firmly fixed and more likely to change to a shrimp-pink. The habit of growth is very strong and branching, the plant making a wonderful showing of bloom as a bedder. No. 1 Grade, \$1.00; Extra Grade, \$1.35.

TALISMAN. Vigorous. Montgomery, I927. A Rose of very recent introduction that has been more freely advertised than any other variety we know of. The color is a brilliant orangeyellow with many of the petals marked with coppery shades. Pictures of this Rose appear everywhere and the demand for it has been phenomenal. We hope the plant possesses the necessary vigor to make it a worthy variety for outdoor planting. The reports so far have been favorable, although this is the first year we have offered it. No. 1 Grade, \$2.00; Extra Grade, $\$ 2.50$.

VILLE DE PARIS. Vigorous. Pernet-Ducher, 1925. This is one of the few good yellow Roses recently introduced. The long-pointed buds and open flowers are a true buttercupyellow, quite vivid and non-fading, and the fragrance is good. The bush is tall and the flowers are borne on long stems, not very heavy but strong enough to support the flowers nicely. A plant of strong constitution to withstand hard winters and bloom continuously all summer. No. 1 Grade, \$1.50; Extra Grade, \$2.00. 


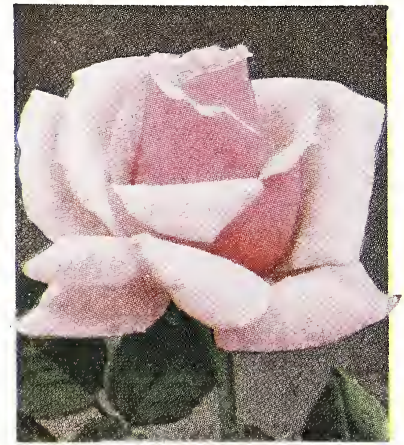

Mrs. Henry Morse. See page 16

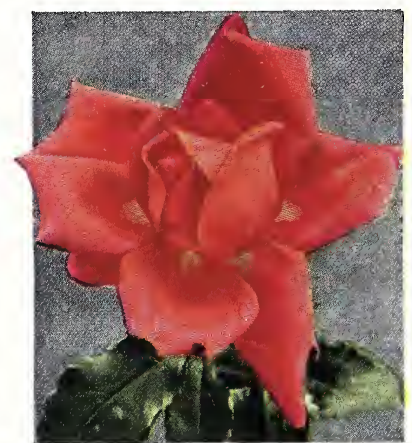

Padre. See page 16

\section{HYBRID TEA ROSES, continued}

WILHELM KORDES. Vigorous. W. Kordes Sohne, 1922. Another Rose of recent introduction. Buds are very pointed and long, of deep golden salmon. When open the flower takes on an entirely different color, petals being marked with shades of reddish copper. Some days no two flowers on even the same plant will look alike. Bush is not very tall but very vigorous and compact. Indeed a very interesting Rose and we hope one that is here to stay. No. 1 Grade, \$1.50; Extra Grade, \$2.00.

WILLIAM F. DREER. Vigorous. Howard \& Smith, I920. This variety, coming to us from the same hands which gave us Los Angeles, is almost a counterpart of that famous variety, except in color. In it will be found more yellow and less pink than in Los Angeles, the colors blending into an exquisite, delicate tone of yellow-flesh-pink. The lover of Los Angeles will find in this variety a relation whose charms will be found most appealing. It is a variety that needs coddling to attain perfection. No. 1 Grade, 90 cts.; Extra Grade, \$1.25.

WILLIAM R. SMITH. Very vigorous. Shellem, I907. A pure-blodded Tea Rose of exceptional vigor and with wonderfully beautiful and absolutely disease-proof foliage. The flower is large, well formed, and very full; attractive both in bud and as an open flower. In color it is a blush, made up of white, pink, and a little yellow. At its best in the late summer and fall, when it is really superb. It is, however, lacking in fragrance, possessing merely a slight Tea odor. This variety will prove especially desirable to those who are troubled with black-spot and mildew, from both of which this variety is absolutely immune. We wish more of our European introductions had the constitution this variety possesses. No. 1 Grade, 90 cts.; Extra Grade, $\$ 1.25$.

NOTE.-The following list of Hybrid Tea varieties, which we offered in past years, are not included in this year's catalog: Cheerful, Frank W. Dunlop, George C. Waud, Mrs. S. K. Rindge, Prince de Bulgarie, Rose Marie, Souv. de Georges Pernet, Sunny Jersey, The Queen Alexandra Rose, and Willowmere. In most cases, new and better varieties have taken their places.

\section{Home Storage of Dormant Roses}

Experienced Rose-planters in northern latitudes where the winters are rather severe have been burying (completely heeling-in) their Roses over the winter instead of planting them immediately in the fall. The method of digging a trench about 2 feet in depth and width, and as long as necessary to hold all the Roses to be stored, is explained more in detail in our Winter Circular which accompanies each fall shipment. The plants may be taken out of the storage-trench in a fine, healthy condition in early spring at exactly the right time you wish to plant them. Roses for home storage should not be shipped before November.

Preserve this booklet for future reference. The text matter in the last part will assist you in growing better Roses 


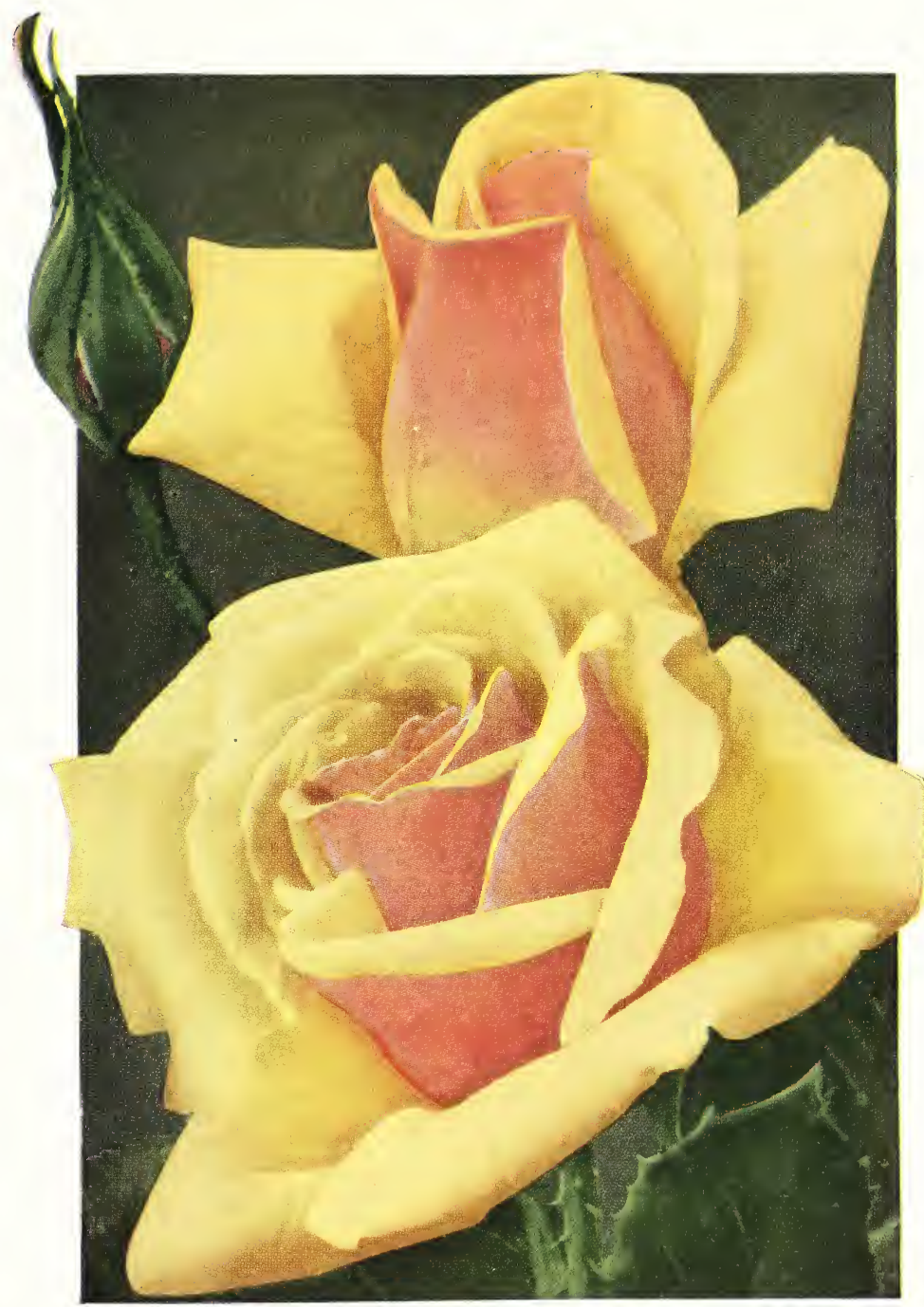

Rev. F. Page-Roberts. See page 17 


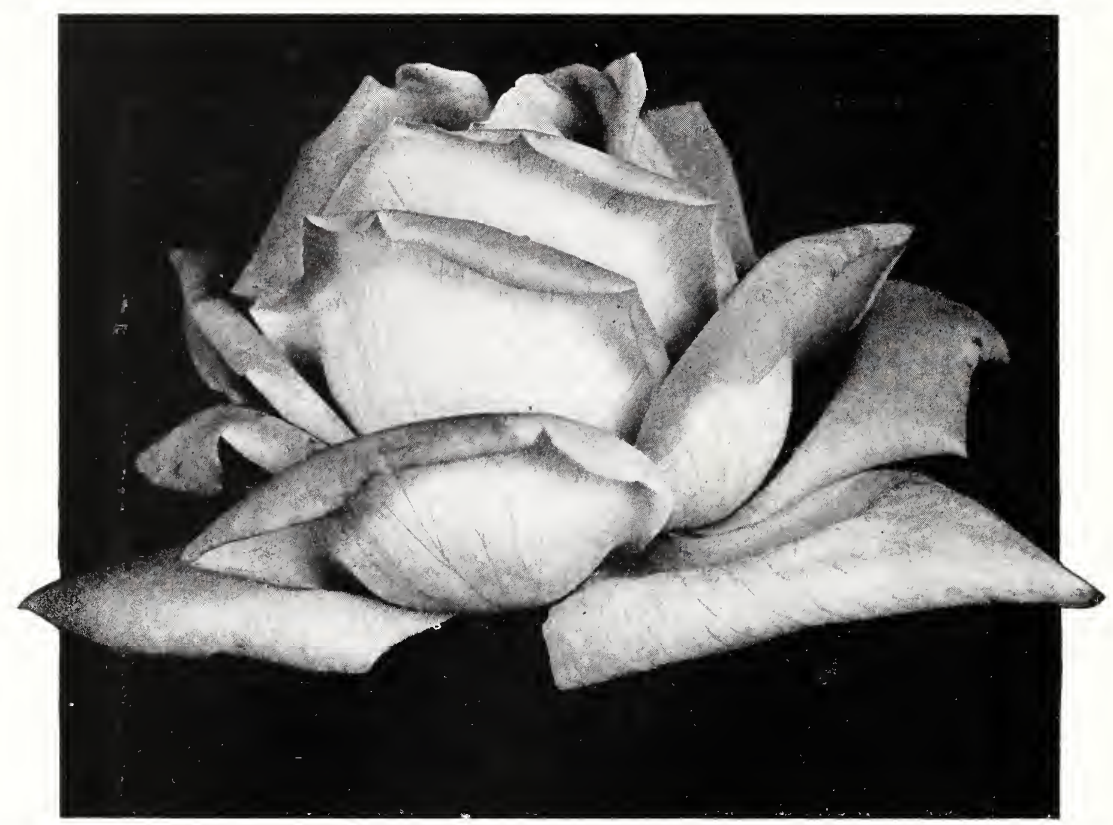

Georg Arends. See page 21

\section{Hybrid Perpetuals}

Of recent years, during the rapid development of the Hybrid Tea class of Roses, there has apparently been a tendency to neglect, to a certain extent, the Hybrid Perpetuals, or, as they are also known, Hybrid Remontants. It is quite true that most of the Hybrid Perpetuals do not give us much, and some varieties no bloom here in the North after their June flowering, but this class of Roses has so many points of merit as to make it, in our estimation, absolutely indispensable to anyone who can plant, say, more than a dozen Roses. In the first place, the Hybrid Perpetuals do not begin to require the care which should be given to the Hybrid Teas in order to have them at their best. Little or no winter protection, as a rule, is necessary except where the winters are of exceptional severity. Then, too, Roses in this class are, almost without exception, of strong, vigorous growth, making bushes from 3 to 6 feet or more in height if desired. The flowers are mostly large to extremely large in size and as a class are much more fragrant than the Hybrid Teas. During their main blooming season, which in this latitude occurs in June, they yield to the plant many more flowers than the Hybrid Teas do.

Take it all in all, this class of Roses remains absolutely indispensable and will continue to prove the crowning glory of the Rose garden in June.

BARONESS ROTHSCHILD. Free. Pernet, I 867. Light pink, large, and very symmetrical. Fine, cupped form; weak in fragrance. Foliage fine and in great profusion right up to flower. Faultless in bush, form, and color of flower, this variety is deservedly popular. Very hardy. No. 1 Grade, 80 cts.; Extra Grade, $\$ 1.00$.

CAPT. HAYWARD. Vigorous. Bennett, I 893. Light scarlet-crimson, full, perfectly formed flower of delightful fragrance. In addition to its other good qualities, this variety is the freest autumn bloomer of any red in its class. No. 1 Grade, 80 cts.; Extra Grade, \$1.00. 


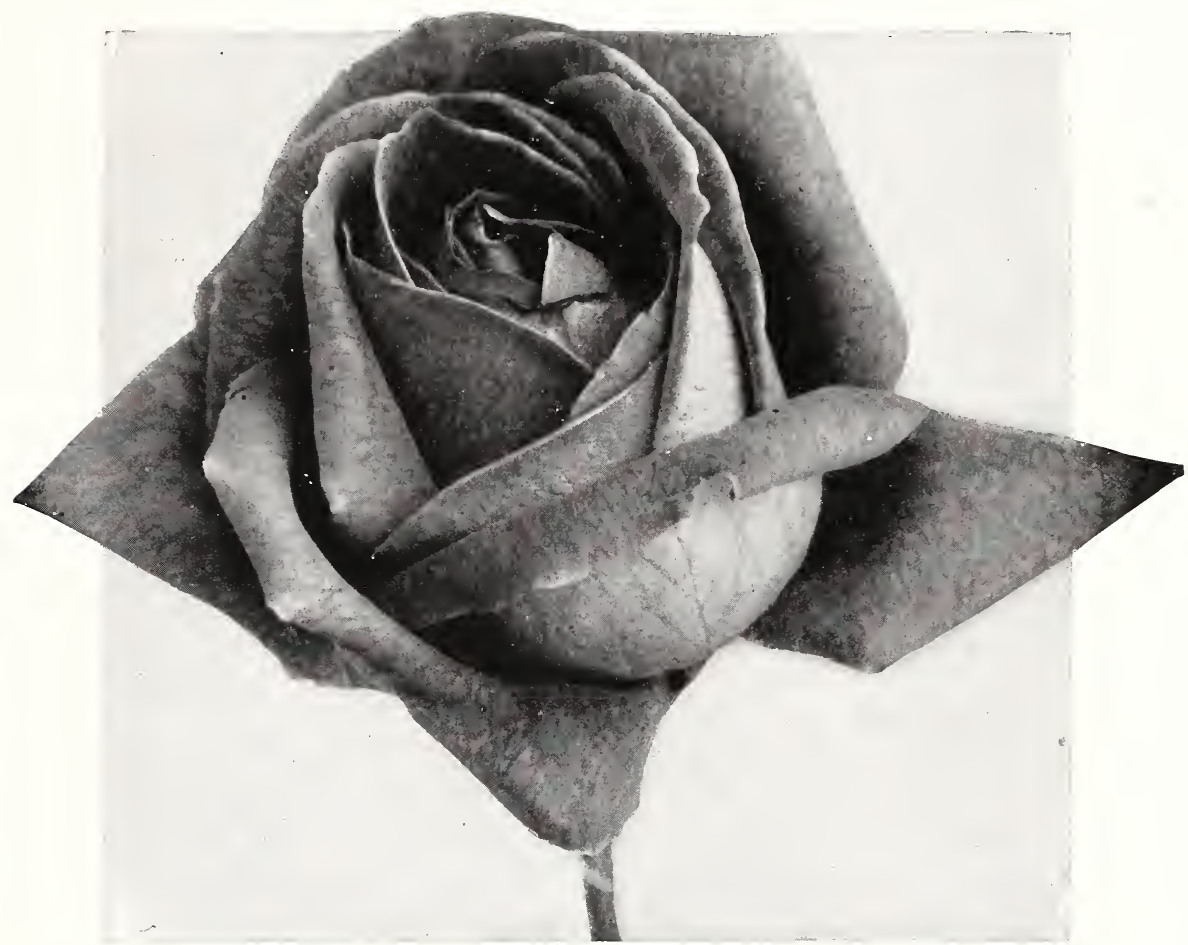

J. B. Clark. See page 22

\section{HYBRID PERPETUALS, continued}

CLIO. Very vigorous. W. Paul \& Son, I 894. Flesh color, deepening in center; large, fine, globular form; very free bloomer. An exceedingly strong grower, with fine, large foliage, setting off a flower as beautiful as it is distinct. Wood closely set with thorns. Buds should be thinned, and near blooming-time kept dry when using hose. No. 1 Grade, 80 cts.; Extra Grade, \$1.00.

FRAU KARL DRUSCHKI, syn., White American Beauty and Snow Queen. Very vigorous. P. Lambert, I90o. This is the queen of all white Roses both in size and purity. The buds, however, are often tinged with pink, but this color appears only on the outside of the outer petals, and the flower opens to a pure snow-white. The buds are of beautiful formation, and the immense, open flowers well filled with petals. The growth is exceedingly vigorous, and the plant is a most prolific bloomer in June and early July (in this latitude). Scattering flowers often appear in the fall as well, although individual plants may not again bloom the same season after the main crop is off. Its main season of bloom is, however, extended over a longer period than that of most Hybrid Perpetuals. No. 1 Grade, 80 cts.; Extra Grade, \$1.00.

GEORG ARENDS. Very vigorous. IV. Hinner, I9IO. This variety, known also as "The Pink Druschki," is one of the most fragrant Roses in cultivation. The flower is very large and full and in color is a soft, light pink. It has good, light green foliage and produces a very pleasing and delicate effect as a cut-flower arranged with Frau Karl Druschki. No. 1 Grade, 80 cts.; Extra Grade, $\$ 1.00$. See illustration on page 20.

Preserve this booklet for future reference. The text matter in the last part will assist you in growing better Roses 


\section{HYBRID PERPETUALS, continued}

GEORGE DICKSON. Vigorous. A. Dickson \& Sons, I9I2. When this Rose was disseminated a few years ago it was heralded as one of the greatest, if not the greatest Rose, ever raised by the originators, who have been among the foremost in producing new varieties of Roses during the past generation. It was introduced (and is still sold) as a Hybrid Tea Rose, but in our opinion it should have been classed with the Hybrid Perpetuals and if purchased as such it will not disappoint the lover of Roses. In color it is the most wonderfully rich, dark red Rose in existence, described by the introducers as "velvety black scarlet-crimson with brilliant reflex tips, with heavy and uniquely pure crimson-maroon veinings on the reverse." The only fault we have observed in it is that the stem immediately below the flower is sometimes rather weak, but this fault, when it occurs, is not serious enough to deter the planting of this Rose, which is of strong growth and good, bushy habit. The flower is very full and beautifully formed; richly perfumed and was awarded a gold medal by the National Rose Society. No. 1 Grade, 80 cts.; Extra Grade, \$1.00.

J. B. CLARK. Exceptionally vigorous. Hugh Dickson, I905. This Rose was introduced as a Hybrid Tea, but after testing it we at once classed it as a Hybrid Perpetual, where now it is generally admitted it belongs. It is an immense, full, red Rose, similar in color to the wellknown General Jacqueminot. Its fragrant flowers come on very long, strong stems, making it ideal for cutting. The growth of the plant is unusually strong, rugged and thorny; in fact, even among the Hybrid Perpetuals it will be difficult to find as strong a grower. Canes from 7 to 8 feet high of one season's growth are quite common. Also it does not bloom again after June, at least in this latitude. Considered as a Hybrid Perpetual, pure and simple, it is a very fine Rose; splendid to plant with Frau Karl Druschki for beautiful contrast. The foliage is also of exceptional size, and a beautiful bronzy green while young. Very hardy. Prune moderately. No. 1 Grade, $80 \mathrm{cts}$; Extra Grade, \$1.00. See illustration on page $2 \mathrm{I}$.

MRS. JOHN LAING. Vigorous. Bennett, I 887. Soft pink; large, perfect flower, with petals of good substance, and of a most delicious fragrance. Produces its blooms on long, stiff stems of almost thornless wood, with large, beautiful, light green foliage right up to the flower. Very hardy. Possesses, in our opinion, more points of merit than any other Hybrid Perpetual Rose for general planting. Fine as it is for garden effect, it is unequalled for cutting purposes. Plant a bed of it - a hundred if you can afford it - and you will be cutting Roses until heavy frosts. Practically an everblooming Hybrid Perpetual. No. 1 Grade, 80 cts.; Extra Grade, $\$ 1.00$.

PAUL NEYRON. Very vigorous. Levet, I 869. Deep rose; flowers very large (the largest of any yet in cultivation) and full; a good, free bloomer. Strong, upright grower, with large, tough foliage; wood quite smooth. After the main blooming season is over in June this variety will send up, during summer and fall, occasional stout $3^{-}$and 4 -foot shoots bearing blooms which, in point of size and fragrance and in beauty of foliage, equal the best "American Beauties" which the skilled florist can produce. Its immense size and strong growth make it exceedingly valuable to mass with Frau Karl Druschki. "The noblest Roman of them all." No. 1 Grade, 80 cts.; Extra Grade, \$1.00.

PRINCE CAMILLE DE ROHAN. Vigorous. E. Verdier, I861. Deep, velvety crimsonmaroon; large and full. In intensity of dark coloring it ranks very high, and all in all is yet about the best very dark Rose ever produced. Good, bushy grower and free bloomer. If you can have but one very dark Rose, this is "it." No. 1 Grade, 80 cts.; Extra Grade, \$1.00.

SUZANNE-MARIE RODOCANACHI. Vigorous. Leveque, I883. Soft rosy cerise. A large, well-formed, globular Rose of great beauty and charm. Magnificent foliage. While not so highly perfumed as some others, this is a really grand Rose, deserving more attention here than it has been getting. In England it has a great reputation. The richest colored pink Rose in the Hybrid Perpetuals. No. 1 Grade, $80 \mathrm{cts}$; Extra Grade, \$1.00.

ULRICH BRUNNER. Very vigorous. Levet, I88I. Brilliant light cherry-red; of immense size (a seedling of Paul Neyron), fine form, fragrant; flowers of great substance and lasting qualities. Wood and foliage very strong and disease-resisting. Wood light, glossy green and almost thornless. A very popular Rose. No. 1 Grade, $80 \mathrm{cts}$.; Extra Grade, \$1.00. 


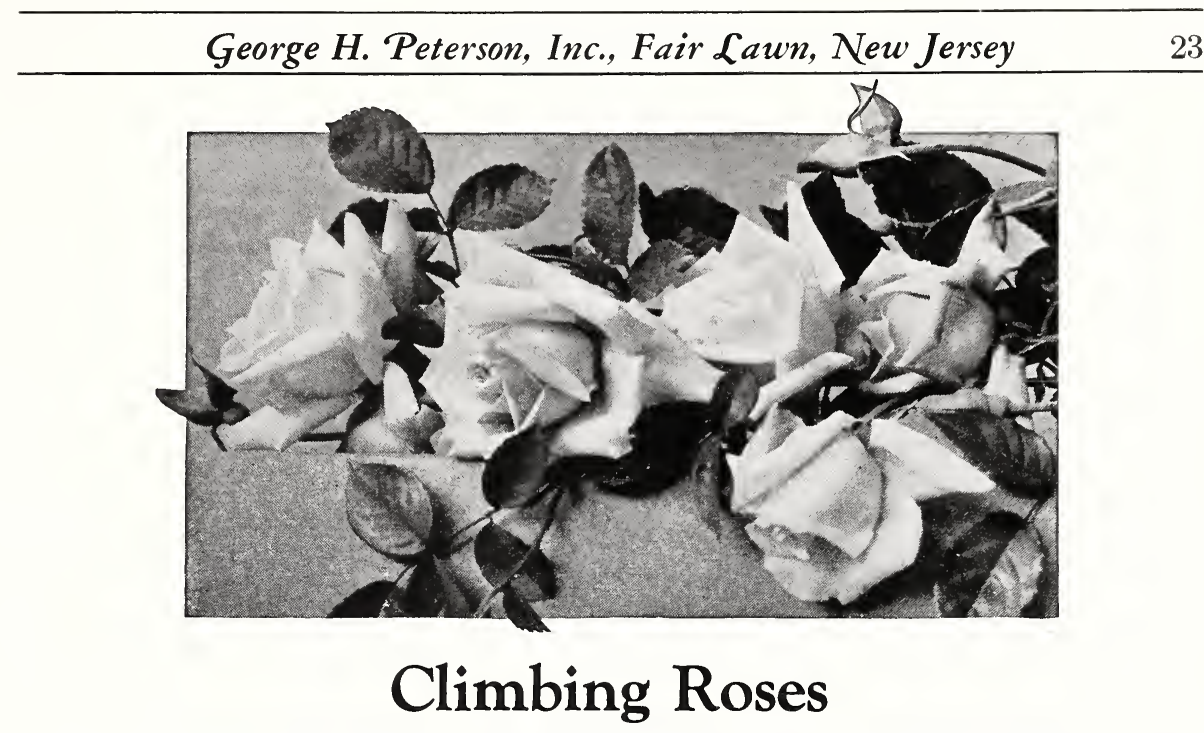

Under this head we find most of the various classes represented. As an ornamental plant for covering porches or verandas, side walls, pillars, fences, etc., they are unequalled, calling forth more admiration than anything else which can be similarly used. They require but little pruning.

All except the Hybrid Teas are hardy, which latter, in the North, should be taken down and covered with clean soil (free from manure and rubbish) to insure wintering. Unlike the Ramblers, they cannot thrive in the North under neglect and must there receive good care. Give them your best possible soil. The Wichuraiana Hybrids are rampant growers and very pliable, particularly adapted to covering porches, trellises, stone walls, embankments, etc. The blooms of these, coming in clusters, cover the plants en masse in their blooming season, which in the latitude of New York City is late June.

AMERICAN PILLAR. Conard \& Jones, I902. A very strong-growing and hardy climber. Large, single flowers of rich, deep pink (almost red) with white center, coming in large clusters. This being somewhat similar to Hiawatha, but with larger individual flowers, we have discarded the latter variety, giving this the preference. No. 1 Grade, 80 cts.; Extra Grade, \$1.00.

CHRISTINE WRIGHT (Hybrid Wichuraiana). Hoopes, Bro. \& Thomas Co., I909. This is a most charming, moderately full climbing Rose of a delightful wild rose-pink color. The flowers are very large for this type of climber and are borne in profusion. Should be more largely planted. No. 1 Grade, 80 cts.; Extra Grade, \$1.00.

CLIMBING AMERICAN BEAUTY (Hybrid Wichuraiana). Hoopes, Bro. \& Thomas Co., 1912. While the name is more or less of a misnomer, this is a very meritorious climber, subject, however, when the weather does not suit it, to fade and turn purplish. The flower is quite large and full, of a bright, medium shade of pink, and the plant a prolific yielder, blooming early for a climbing Rose. No. 1 Grade, 80 cts.; Extra Grade, \$1.00.

CLIMBING KAISERIN AUGUSTE VIKTORIA (Hybrid Tea). A. Dickson \& Sons, 1897. A strong climbing sport, identical with the parent plant, except in habit of growth. (See Hybrid Tea section.) Makes an exceedingly chaste pillar Rose but in the North not of sufficient strength and bushiness of growth to cover a veranda. No. 1 Grade, 80 cts.; Extra Grade, \$1.00.

CLIMBING MME. CAROLINE TESTOUT (Hybrid Tea). Dhauvry, I902. A very strong, climbing sport from this well-known pink Hybrid Tea, which is an immense, full flower of richest pink. The best pink everblooming climber. No. 1 Grade, 80 cts.; Extra Grade, $\$ 1.00$. 


\section{CLIMBING ROSES, continued}

DR. HUEY (Hybrid Wichuraiana). George C. Thomas, I9I4. A moderately large, semifull flower of the deepest crimson-maroon with a blackish luster, resembling in color the Hybrid Tea, Chateau de Clos Vougeot. It is unquestionably the darkest of the climbing Roses. The plant is vigorous and the blooms are borne in great profusion. No. 1 Grade, 80 cts.; Extra Grade, \$1.00.

DR. W. VAN FLEET (Hybrid Wichuraiana). Henderson, I9Io. This variety, like Silver Moon, gives us some of the largest flowers yet produced in the Wichuraiana Hybrids. The individual flowers, coming 3 inches or so in diameter, are produced in masses of bloom, characteristic of this class of climbers. The color is a delightful shade of delicate flesh-pink, the flowers being borne on quite long stems, making it a very good variety for cutting, as well as garden decoration. Very vigorous, strong grower, with beautiful, bronze-green, glossy foliage. No. 1 Grade, 80 cts.; Extra Grade, \$1.00.

GARDENIA (Hybrid Wichuraiana). Manda, I 899 . This is undoubtedly the best hardy yellow rambler and is a prime favorite with Dr. Robert Huey, the famous amateur rosarian. It is an exceedingly strong grower, with the beautiful, glossy green foliage characteristic of the Wichuraianas. Where a yellow climber is wanted, we can recommend this very warmly. Especially attractive in bud. No. 1 Grade, 80 cts.; Extra Grade, \$1.00.

JACOTTE. Moderately vigorous. Barbier \& Co., I920. Unique among hardy climbers in its vivid orange-yellow flowers which are freely produced early in the season. It is about the same color as Independence Day at its best, but the flowers fade to light yellow instead of to pink. The foliage is remarkable for its angularity and glossiness, and would make a handsome plant if it never threw a flower. Rather slow to get started, Jacotte may require two full seasons of growth in your garden before its full splendor may be appreciated. No. 1 Grade, $\$ 1.00$; Extra Grade, $\$ 1.50$.

MARY LOVETT (Hybrid Wichuraiana). Lovett, I9I5. This is probably the very best of the full, pure white climbing Roses. The blooms are borne in masses on a strong-growing dark green, glossy foliage plant. Brought into being by the same hand that produced Silver Moon and is a worthy companion to that variety. No. 1 Grade, \$1.00; Extra Grade, \$1.25.

MARY WALLACE (Hybrid Wichuraiana). Raised by the late Dr. Van Fleet and introduced by The American Rose Society, I924. This from the hands which gave us both Dr. IV. Van Fleet and Silver Moon, is destined to become equally famous with those varieties. The flower is a large, semi-full one, cupped in form, showing a golden center. The color is pink and one of the most entrancing shades of that color. It is a good, healthy grower, sending up many strong canes yearly from the base and can be grown as either a climbing or a strong Pillar, more or less self-supporting. We like this variety more and more each year and warmly recommend it to the planter who has a place for a Rose of this character. No. 1 Grade, 80 cts.; Extra Grade, $\$ 1.00$.

PAUL'S SCARLET CLIMBER (Hybrid Wichuraiana). IV. Paul \& Son, I9I6. While this variety contains Wichuraiana blood, this trait is not pronounced. Both the foliage and flower are large for a climbing Rose; in fact, this variety makes quite an attractive cut-flower. Its chief distinction is its wonderful glowing color which immediately catches the eye and evokes admiration from the beholder. While a reasonably good grower for a climbing Rose, it is not so robust in this respect as, for instance, Silver Moon. It will, however, cover any trellis or veranda of reasonable size. No. 1 Grade, 80 cts.; Extra Grade, $\$ 1.00$.

SILVER MOON (Hybrid Wichuraiana). Henderson, I9IO. During the past I5 years, this climbing Rose, together with its companion, Dr. W. Van Fleet, has been propagated and sold more freely, perhaps, than any other climbing Rose. It is practically a single Rose of enormous size, pure white with a center of golden stamens. It is borne against a background of the most beautiful, glossy, bronzy green foliage to be found in Roses. The growth is unusually luxuriant, making canes from Io to 20 feet in a season. It is now, in fact, so well known as to make a more extended description unnecessary. It will be many years before it is displaced. No. 1 Grade, 80 cts.; Extra Grade, $\$ 1.00$. 


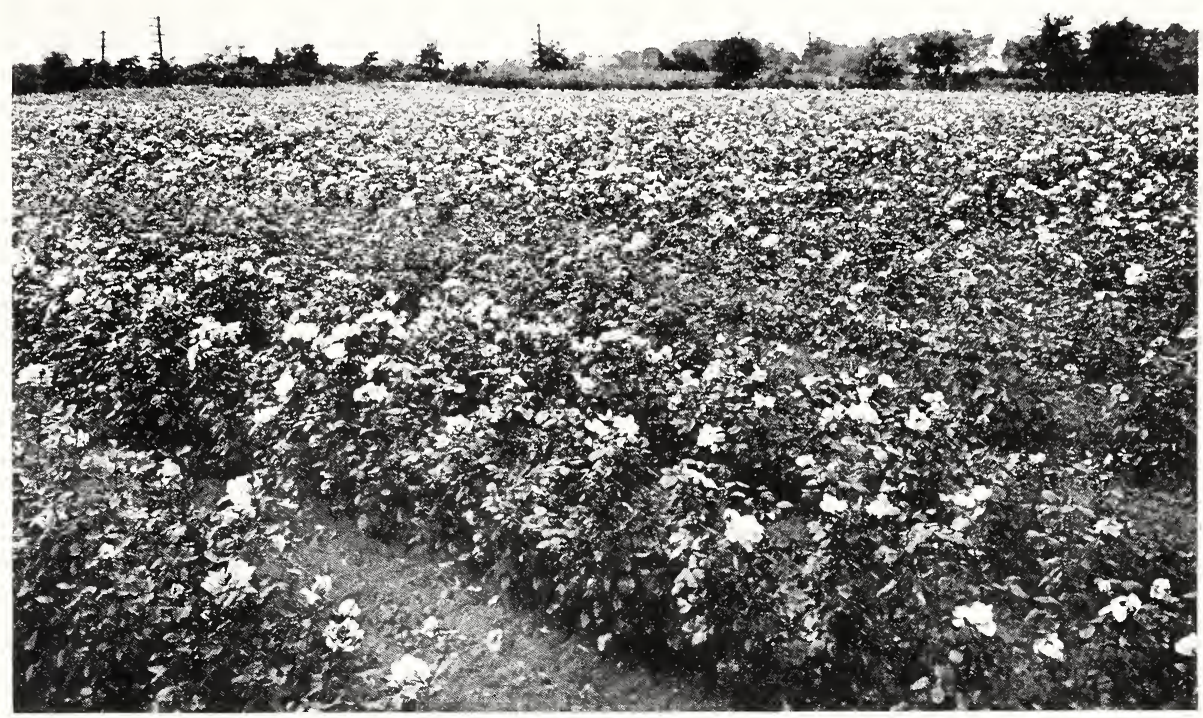

One of our Rose fields

\section{The Culture of the Rose}

LOCATION OF SITE. This, the first step, is important. The Rose garden must not be situated directly under the branches of trees, but away from all trees and large deciduous shrubs as their roots usually extend much farther than their branches. Lately we are inclined to quality this statement just a bit and say that in some cases, especially with some of the weaker growing varieties, partial shade during the hot summer months at least is desirable. We have recently noted some varieties doing exceptionally well in partial shade, provided the situation is such that there will be plenty of air circulation. So that in general, an "open" situation, yet sheltered if possible from high winds, but where the plants will get enough air and sunshine will give you the ideal location. While a southeastern exposure is probably the ideal one in which the garden will reach its fullest development, still the flowers will retain their dewy morning freshness longer (and it is in the early morning that the Rose is at its best) if the beds are placed where the morning sun is slow in reaching.

Do not plant close to the foundation wall of a building. In such a location the ground does not get the benefit of average rains and, as summer advances, the heat there will be too great.

Where one resides in a city or town, the choice of location for a Rose bed or garden is often quite limited, yet despite this handicap there are many thousands of Rose culturists so situated who are very successful.

SOIL. The ideal soil is what may be termed a clay loam. This is of an adhesive nature, but should be sufficiently porous to permit the ready drainage of surplus water and in this respect a sandy loam will of ttimes produce nearly as fine Roses as a clay loam. Any good garden soil which will produce good vegetables will, with proper fertilization, yield very fine Roses. A too-heavy soil may be improved by working into it a little coarse sand and vice versa.

Preserve this booklet for future reference. The text matter following will assist you in growing better Roses 
MANURES AND FERTILIZERS. This, while not a very pleasant topic or article to handle, is nevertheless a most important one. Partially rotted animal manure is the most desirable; cow manure is generally preferred by rosarians as it can be used most liberally without danger of burning and is most useful in holding moisture in the soil. Fresh horse manure is very heating and should not be used while in this condition except as a winter mulch and even then should not be applied heavily at once, several light applications a few days apart being better.

Hog, sheep, and chicken manures are also very useful; to the latter should always be added a small amount of acid phosphate. Whatever manure is used, it is essential that same should be thoroughly broken and mixed with the soil and if this is done in a thorough manner, quite fresh manure may, if necessary, be used.

Where manure cannot be obtained-and we realize only too well it is becoming scarcer and more difficult to obtain every year both in the city and country because of truck and automobile rapidly replacing the horse-ground bone is probably the best substitute to supply food. This may be obtained in several degrees of fineness. Our own practice is to mix fine bone-meal, medium ground bone-meal, and coarse crushed bone. In this way we obtain both immediate and lasting results. This may be used separately or to supplement animal manures. After the beds are well dug, scatter the bone on the surface until the ground is about covered; then, with the use of a spading fork, it can be thoroughly mixed with the soil.

A high-grade commercial fertilizer will also supply the necessary plant food, but, of course will not assist very much in giving a soil the ideal physical conditions that either manure or rotted sods will. We do not recommend the application of commercial fertilizer at time of planting, whether the planting be done in the fall or in the spring. It may be used the following June or July after fall planting and after the Roses are pretty well established and have bloomed freely for the first time. A moderate handful to a plant will be sufficient but it should be well watered and hoed in thoroughly immediately upon application. For reasons under "Summer Pruning," we advise against any fertilizing later than the latter part of August.

Commercial fertilizer may also be applied in the form of food tablets. The Plant Products Company, of Baltimore, Maryland, manufactures a tablet under the trade name of Fulton's Plantabbs which contains a rather high potash content and makes, therefore, a desirable plant food for Roses. By dissolving three or four Plantabbs in a gallon of water, one is able to apply fertilizer very easily. Plantabbs may be bought at any reliable seed store.

Do not be afraid to use commercial fertilizers and dried concentrated manures; sooner or later we shall have to depend more upon them. Of course, exercise a bit of judgment in their use, as surely those with the true "plant instinct" always do. Do not be tempted to use a fertilizer high in nitrogen content which will give you quick but not lasting results.

We recommend the use of Unleached Hardwood Ashes as a good fertilizer high in potash and one to sweeten the soil. A mixture of one-half bone and one-half ashes, a generous handful applied and worked about each plant approximately three times during the growing season, is good and safe to use. Please remember it is the potash content in fertilizer that will be mainly responsible not only for the deeper tones of the colors of your flowers, but will also ripen the canes of the bushes so that they may become harder and tougher to withstand even severe winters.

Air-slaked Lime is good to apply from time to time especially on an old bed where the soil may be a bit acid, but remember the action of lime is merely to release plant foods already present in soils and make them more readily available for plant consumption, but in itself is not a fertilizer. Never mix lime and bone-meal (as we recommend ashes and bone above) nor apply to beds at the same time.

PREPARATION OF BEDS. Although good Roses can now be grown from our field-born plants in any good garden soil without special preparation, where the best attainable results are desired the beds should be "trenched" to a depth of I 5 to i 8 inches, i. e., the soil should be removed to that depth, well broken up, and thoroughly mixed with rotted animal manure, using about one part manure to three parts of soil. This mixture, when returned to bed, should be trodden down until desired grade is reached, or, if the bed is prepared well in advance of planting, left for heavy rains to settle.

In a low situation, or where the water does not gradually disappear after a rain, drainage may be necessary. This may be effected by removing another section of soil, about 8 inches, and filling in with stones, broken bricks, or other similar substances, the smaller pieces on top, 


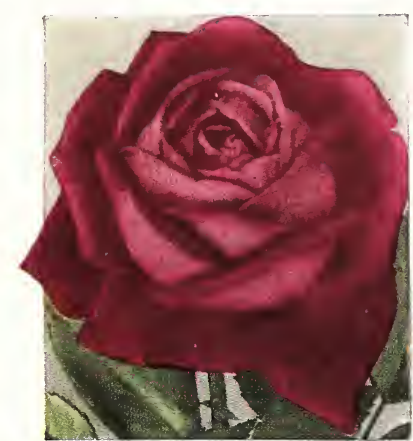

Laurent Carle. See page 13

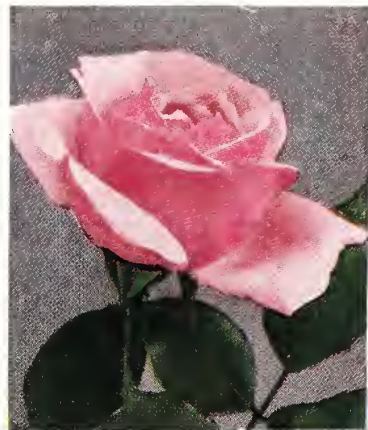

Radiance. See page 17

and the whole given a coating of gravel or ashes to prevent the soil washing through. It is only when you are forced to plant in a low and poorly drained location that we recommend such drainage methods.

While we do not wish to belittle the idea that preparation of the soil is very important, yet we are beginning to believe that subsequent treatment after planting is almost as important as the soil we start with. Many beginners are worried lest their soil is not exactly of the proper physical and chemical make-up, thinking their rose problems are solved once and for all if the soil is ideally adapted either naturally or by painstaking methods of preparation. In other words, we believe that by judicious methods of feeding, cultivating, spraying or dusting, watering, cutting and pruning, that on only an average soil just as good results may be obtained as where all of your time is given over to preparation and thereafter the Roses are expected to help themselves along.

\section{Planting}

DISTANCE APART. Hybrid Perpetuals should be planted about 2 to 3 feet apart, the distance being governed by the space at one's disposal, the varieties planted, and the length of time the planting will probably remain undisturbed. Hybrid Teas and Teas require about I5 to 20 inches; the distance will often depend on the habit of the variety if a mass planting is to be made. In other words, the stronger growing varieties will have to be spaced a little further apart than the moderate growers. In general, for Hybrid Teas especially, we recommend close planting.

HOW DEEP. If the plant has been budded low (as all of our Roses now are), it should be set so that junction of top with root-stock is just nicely covered, certainly not more than one inch. It is most desirable as an aid to setting the plants at the proper depth that the prepared soil in bed or border be raked nice and level before the planting is begun and that but one hole at a time be dug. Dig this about I 5 inches in diameter and varying in depth according to character of the particular root to be set, say about 10 inches on the average. The hole must not be as deep as the length of the roots or the latter will all go together as the soil is filled in. Spread the roots out in all directions at the bottom of the hole and fill in slowly, shaking plant gently meanwhile.

Tread the ground firmly over the roots with feet as each plant is set. This is most important.

WATERING. Whether plants are set in the fall or spring, it is always advisable to water thoroughly at time of planting. Do this watering when the hole is two-thirds filled with soil and after tamping with feet is thoroughly done. The ground will be firm, but fill the hole with water and allow it to drain before completely filling the hole with the remainder of the soil. Remember that the plant is going to sleep in the fall so that this one watering should be sufficient unless we experience a very dry spell. 
ON UNPACKING. If the atmosphere is dry, the plants should be placed in a tub or bucket of water of sufficient depth to cover the entire root system. The degree of care given while planting should be governed by the character of the weather and length of time that will be consumed in the operation of planting.

If the package has been materially delayed in transit, or damaged so that the roots are exposed and in consequence the wood, even though green, appears shriveled, or bark wrinkled, the plants so affected should be at once buried for three days in moist soil as per instruction card which accompanies each shipment.

\section{Pruning}

Just before digging Roses in the fall we cut the bush plants back to about $\mathrm{I}$ foot in height. This is a nice height for handling in both shipping and planting. No further pruning until early spring will be necessary. Climbing Roses we cut back to 2 feet.

SPRING PRUNING. In March, or after all snow is melted, and before growth begins, the canes should be pruned back severely, even if the wood is alive to the ends which is not likely where the winters are severe. The general rule is to cut the weakest canes the shortest, and where these are numerous, some of the smallest ones may, to advantage, be cut out entirely. The severer the pruning, the larger the flowers to follow. A moderate pruning will yield more flowers of less size. We would advise that the stoutest canes be cut back to not more than 6 inches and the weaker ones to 3 inches, referring to Hybrid Teas only. Now in the case of Hybrid Perpetuals, pruning should not be so severe, cutting back the green stems within 8 to 2 inches from the ground.

SPRING PRUNING OLD PLANTS. The wood of the previous season's growth may be treated as advised above. This wood is smoother and greener than older woods. All dead and very old wood should be cut away entirely.

The strong-growing Hybrid Perpetuals need not be pruned so severely as the Hybrid Teas.

The Climbing Roses after becoming established will require but little cutting back. The old, rough canes should be removed to the ground and the lateral or side growths from younger canes should be cut back to about three eyes.

SUMMER PRUNING. At the end of the first or main blooming season, which in this latitude comes in late June, a medium pruning will result in a more bounteous crop of bloom later on. Where the flowers were not cut with a liberal stem, the latter may now mostly be cut back two-thirds or so of their length. Do not, however, cut all growths back nor prune severely as advised in the spring. So severe a pruning will disturb the balance between top and root and will seriously check the growth.

We do not advise later summer pruning nor fertilizing since both will have a tendency to promote late growths which will not have time to ripen or harden for the winter.

\section{Diseases and Insects}

BLACK-SPOT. There are two main general diseases to which the Rose is subject; viz., Black-Spot and Mildew. The former, as its name indicates, appears as a black or brownish spot on the foliage. It rarely puts in an appearance until about the close of the first blooming season in June. It always appears first on the lowest foliage and works upward. As a result, this disease will often practically defoliate the bush. It will not kill the latter but will check the growth and bloom for the season.

MILDEW. This is shown in a grayish, crinkled appearance of the foliage. Like black-spot, it is of a fungous nature, the spores fastening themselves on the bottom of the leaf and spreading rapidly unless checked. It is most likely to occur where the air-circulation is defective or confined and particularly after cold nights following warm days.

Treatment of Both. The two diseases mentioned may now be controlled by the use of Pomodust or Pomogreen (a new preparation with coloring added so that it will not appear as sulphur on the foliage). Both of these preparations are made up of nine parts of a very finely prepared sulphur and one part of lead arsenate. 
Slugs. There is, too, in this mixture, enough arsenate of lead to keep the foliage free of slugs or green "worms" of various kinds which ordinarily feed thereon.

Applying Powder. This powder may be best applied by using a powder-gun of some type. These are sold by the larger seed houses. For the sum of one dollar or so a small gun may be obtained which will suffice where one has say less than ioo plants.

The ordinary powder bellows will do if nothing better is obtainable, or one may even deftly throw the powder on by hand. The modern high-pressure dust-gun will, however, distribute the powder most evenly and economically.

When to Apply. We used to recommend that this dust be applied early in the morning while the foliage is wet, but lately our scientific brethren advise that it may be just as well applied while the foliage is dry and still be effective. It is most necessary to apply this powder just before an expected rain, although if we do not have rains for long periods, do not hesitate to apply this powder every week or ten days.

Pomodust may be obtained from your seedsman or by applying direct to the manufacturer, the Niagara Sprayer Co., Middleport, N. Y.

Their prices f. o. b. Middleport are: Io lbs. \$I.30; 25 lbs. \$2.40; 50 lbs. \$3.80; I oo lbs. \$6.60.

Early in the spring, before growth begins, all dead leaves should be gathered and destroyed. At that time a thorough spraying of the dormant plants and soil with Lime-Sulphur will help to give a clean bill of health at the start. This mixture may be purchased at seed stores in concentrated form.

The Niagara Sprayer Co. also sell a general purpose dust under the trade name of All-inOne Dust. It has sulphur as a fungicide, lead arsenate as an insecticide against chew ing insects, and a small nicotine content for aphis (sucking insects). The quantity of lead arsenate or the quantity of nicotine is not sufficient to control an infestation of either chewing insects or aphis, but our recommendations have always been that if one dusts every io days with Niagara Allin-One Dust or Pomodust, his flowers and shrubs will always be free from insects and diseases as it prevents any of these getting a start. Their prices f. o. b. Middleport are: Io lbs. \$3.30; 25 lbs. \$7.40; 50 lbs. \$I 3.75 ; IOO lbs. \$26.50.

APHIS OR GREEN FLY. A sluggish, often wingless, little sucking insect, which sometimes gathers in countless numbers on the tips of the new growths. Tobacco in some form will quickly dispose of them if used before they are too numerous, when it may require persistent efforts to dislodge them. Either Black-Leaf 40 or one of the new Pyrethrum sprays is effective in killing aphis.

ROSE-BUG OR CHAFER. A familiar insect whose appearance is, fortunately, limited to about three weeks in early summer. In some localities, quite troublesome; in others, rarely so. A very stupid insect, usually found feeding on the petals of white or light-colored Roses, and when touched or jarred will, especially in the early morning, readily fall into a vessel containing a little kerosene. They can be poisoned; but as they do not appear until the flowers are open, the latter will be spoiled by an application sufficiently strong to produce the desired effect.

Various so-called remedies are annually advertised, but we have yet to find one that does not either disfigure the flowers or vilely scent them.

\section{Canker Infections}

For the past three years there has been considerable research work carried on by our plant pathologists in connection with the various cankers attacking Roses. Infections of Brown Canker, Brand Canker, and Cane Canker seem to be prevalent in certain localities, especially throughout the East. It will most likely be another year before these experiments will be completed. At present, opinions relative to definite control remedies vary considerably. Since we believe at present that all canker infection is caused by spores of certain funguses, our recommendation is to spray with a $4-4-50$ solution of Bordeaux Mixture as a preventative. Throughout the entire growing season our fields have been sprayed very frequently with Bordeaux and, as a result, the plants are in fine condition. We have absolutely controlled black-spot, which brings us to a very important point, i. e., the first step in the control of canker infection is to control black-spot; the two diseases seem to go hand in hand.

If you notice any dying back of the canes from the tips, we recommend that such dead wood be removed immediately, cutting back to below where the wood remains alive. It seems that 


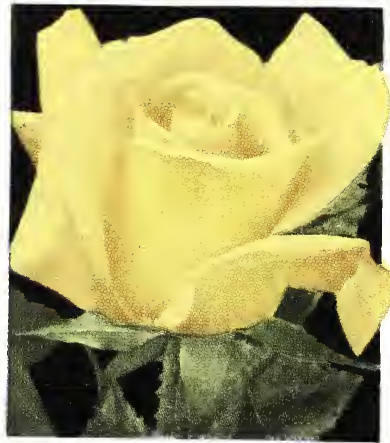

Souv. de Claudius Pernet See page 17

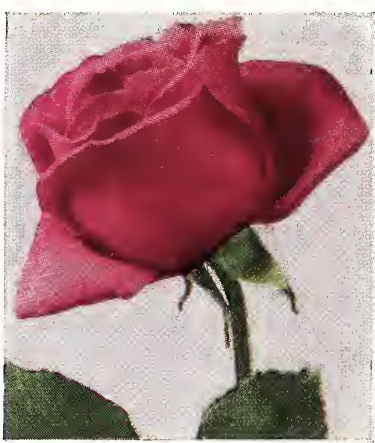

Red Radiance. See page 17

this dying back on certain canes and stunting of plants occurs after the first main flowering period in June or July. The assumption that large and noticeable canker blotches on the canes is first evidence of infection is not correct. Canker may be present in a Rose bush for a considerable time and be the cause of stunted growth long before any definite canker blotches appear. Write to us if you feel the need of more specific information about Canker, because it surely is a subject that all real Rose lovers should be deeply interested in.

It is our belief that the exceedingly wet summers of 1927 and 1928 were responsible for much of the fungous infection, not only on Roses but on many of our valuable trees and shrubs and even vegetables. Let us hope now for a year of normal weather activities.

\section{Winter Protection}

Except where the winters are very severe, the Hybrid Perpetuals will require no protection. As a precautionary measure, however, and to conserve their vitality, it is a wise thing to hill up the soil around each plant to a height of a foot or so if this can be done. In the latitude of New York City or thereabouts, this operation should be done about the middle of November. Some three weeks earlier will do no harm in case one has to leave his country home.

Hybrid Teas will require more thorough protection in latitudes north of Philadelphia to Washington, D. C. When hilling up-hoeing and pulling the ground in the bed up about the stalks or canes - especially if the Roses, as in the case of Hybrid Teas, may have been planted rather closely, it is sometimes necessary to bring a few wheelbarrow loads of soil from outside of the bed so that too much soil may not be taken up from on top of the roots in order to cover the canes. Furthermore, the valleys thus made by this hilling-up process may well be filled in with stable manure if available. This will serve both as a protection to the roots over winter and will fertilize the soil for the coming season. If new horse manure is used, two or three light

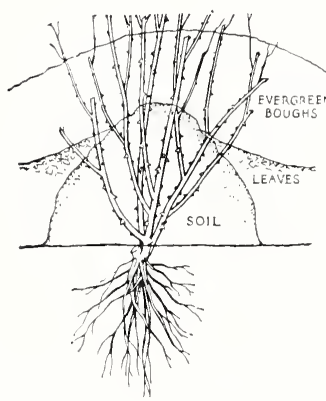
applications will be advisable since, if this is applied in bulk, more or less heating will result. The manure should be applied a week or so after the hilling-up has been done and after we have had a few heavy frosts. On top of this, along in December, or when the ground is well frozen, a covering of any porous material will prove an added protection where the winters are very severe. For this purpose leaves, straw, hay, fine cornstalks, small evergreen boughs, burlap, or some other similar material may be used. This will help to keep the ground frozen throughout the winter, which is highly desirable, since frequent alternate freezing and thawing may work much harm.

In late March, or as soon as the frost is out of the ground, this covering should be gradually removed. Some of the material might be left nearby ready to throw over the plants lightly should a night of severe freezing threaten. 


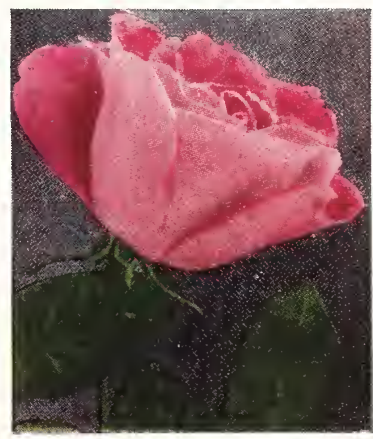

Killarney Queen. See page 12

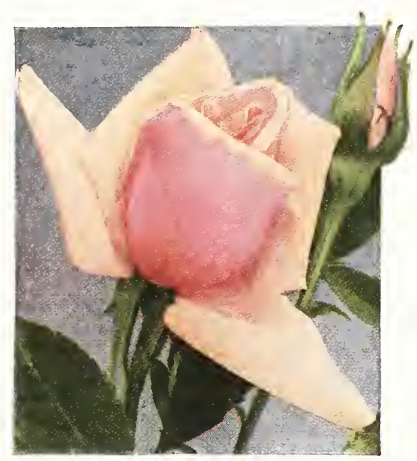

Lady Pirrie. See page 13

The surest method of wintering more or less tender Roses in very severe climates is to dig them up in November, tie them in bunches, and bury them, root and top, a foot and one-half or more deep but in a well-drained location and replant in the early spring. The objection to this, however, is that one loses the advantage of the plant being established in the ground and then, too, trying spring weather may be experienced, which is always harder on newly set plants than on established ones.

The matter of wintering one's Roses is gone into in more detail in a circular which is sent with each order.

\section{Our New Office and Nursery}

We are now comfortably settled in our new quarters. During the past year we completed the building of a new office and sheds at our beautiful new location on the Paramus Road (Route 2) just midway between Hackensack and Ridgewood. This is four miles directly east of the old office; the Fair Lawn Station is practically half-way between our old and new location. We thoroughly believe our new packing and storage sheds are better adapted for the proper and efficient handling of Roses and Peonies than any of like construction we have yet seen anywhere. Furthermore, the hundred or more acres of land we have to rotate our Peony and Rose crops on will undoubtedly give us better plants than ever before. Due to the very nature of our methods of propagating, we still have a few acres of Peonies in our fields at Fair Lawn. The plantings made last fall on the new farm give promise even now of producing for us a wonderful crop of one-year Peony roots.

Our many thousands of Roses for this fall's and next spring's sale and delivery are maturing on the old farm in Fair Lawn, and what a crop of Roses there has been the whole summer long!

Our new president, fully experienced and in the prime of life, and the entire old Peterson organization will be pleased to welcome visitors. Especially next year, when we shall have all of our maturing crops on the new farm, we hope to see many of you during the flowering seasons.

\section{Potted Roses for Late Spring Planting}

In past years, during our spring shipping season, we have been obliged to return many orders received too late for planting dormant stock. To satisfy such customers, we can now furnish, about May I and thereafter, field-grown plants which we have potted in 6-inch pots during the winter and carried over in deep coldframes. They may be planted during late spring and early summer and are very convenient to fill in vacant spaces here and there in your garden. They will be growing and even may be in bud when you receive them, but may still be planted with an absolute degree of safety.

The list of potted Roses, while containing a representative collection of varieties in all colors, may not contain all the varieties as listed in our catalog. However, when requested or given permission to assist you with the selection, you will always receive more than full value. Prices will be the same as for dormant stock. 


\section{A Path to the Rose Buyer's Feet}

Below will be found extracts from unsolicited letters recently received. Permission to use them was asked for and in all cases cheerfully granted. They represent but a small fraction of similar letters which have been received since the issue of our last Rose Catalog but the printer says there is room for no more. Where our stock is unknown, we hope these few letters will prove it is all or more than we claim it to be.

88 Michigan Ave., South Haven, Mich., May $20,1929$.

Each year I am more enthusiastic over Peterson Roses. My little bed of between 50 and 60 is a wonder to many, and the established bushes grow better each year. In fact. I have a few bushes purchased of you by my father in I908. and last summer, during one week in August, I picked I 2 large Roses each with a 3-foot stem and all from the same bush! Nct bad fcr a 2 I-year-old bush.MrS. R. S. MCCRIMINON.

I648 Hamlin St., N. E., Washington. D. C., September 12, 1928.

I have won many blue ribbons in neighborhood flower shows with Peterson's Roses. . . . In spite of two years reglect, mcst of your bushes have survived and can be brought back into shape with a little care. I think that only Peterson Roses could have survived such an crceal.-CAPT. Arthur W. BeEr.

The Three Oaks, Hempstead, L. I., N. Y., June 5, I929.

The Roses planted in October do beautifully for me. I wish that you could see the Roses that you sent me last autumn. They are fire plants, blooming well.-MRS. H. V. R. KENNEDy.

I 8 Paul Ave., Syracuse, N. Y., August 22, I929.

I've had real joy out of the stock bought from you. They are the kind of plants that make a real Rose-lover's eyes glisten because he knows he will get a good crop.-R. J. JoHnson.

Owingsville, Ky., November 7,1928 .

Tre Roses came in splendid condition and I thank you for the handsome specimens that you kncw so well how to produce.-Mrs. William E. Richards.

I 20720 th St., La Salle, Ill., September 29, 1928.

This is the third year I have bought of you and of course I am mighty proud to report that Peterson's Roses have been the marvel of the town.-W. A. JAkowsky.

R. R. 7, Box I300, St. Louis, Mo., August 23, I929.

I am very well pleased with the plants you sent. We are having extremely hot, dry weather now but 1 wish I could show you the lovely bouquet of your Roses I have before me-Hugo F. BUDER.

3 Essex Rcad, Summit, N. J., October 20, 1928.

Would like to thank you for sending such splendid stock-all "Extra Grade" - and worthy of the "Extra" in title and in price.-Mrs. W. A. KigGins.

687 Congress St., Portland, Maine, October I9, 1928.

I am getting good Roses now from the ones planted last year. After having Peterson's Roses for Io to I5 years we are somewhat hard to please. Your Roses and peonies are wonderful._-Dr. HENRY H. BROCK.

R. R. 4, Jackson, Mich., November 13, 1928.

I want to thank you for the fine stock. It made me say: "I ain't ever seen Rose bushes betore." We feel that we got our money's worth.-Mrs. P. A. Miller.

I64 W. Utica St., Buffalo, N. Y., October $30,1928$.

The Roses you recently sent me were certainly splendid, vigorous plants. It is a pleasure to obtain such stock.-Edwin T. Allen.

342 Madison Ave., New York, N. Y., October I8, I028. a healthier or finer looking lot of Rose bushes.-RICHARD OUTwater.

459 S. Main St.. Adrian, Mich., September $28,1928$.

I have had very good success with your Roses. Everyone in the city admires them.-MRs. F. W. Prentice.

Valley Brook Farm, Bryn Mawr, Pa., October 20, I928.

Please find check enclosed with thanks for sending me such fine Roses. Your Roses always give me great pleasure.-Mrs. GEORGE F. Huff.

I had very good success with the plants I bought from you last fall. They all started well but one.-E. A. FIFE.

The Roses I bought from you last fall satisfied with them.-WM. E. CATHCART. 
FALL 1929 - SPRING 1930

GEORGE H. PETERSON, Inc., FAIR LAWN, N.J. The use of this ORDER SHEET will insure the prompt and correct filling of your order.

NAME

MAIL

ADDPESS

EXPRESS $\{$ if different

ADDRESS $\{$ from above $\}$

NUMBER

RECEIVED

SIHIPPED

Amt. Enclosed

BY

\section{SHIP ABOUT}

Shipping Seasons: In Fall, early Oetober through to late November.

In Sprinǵ, middle of March through Month of May; after May Ist, potfod stouk.

PLEASE INDICATE IN FIGURES, IN COLUMNS

MARKED "QUANTITY", HOW MANY OF EACH VARIETY ARE WANTED.

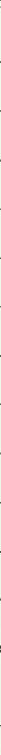


PLEASE INDICATE IN FIGURES, IN COLUMNS MARKED "QUANTITY", HOW MANY OF EACH VARIETY ARE WANTED.

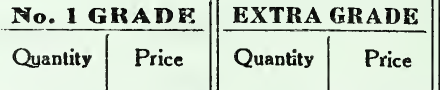

TOTAL

Dollars Cent

Quantity

Price
FORWARD

HYBRID TEAS

ANGELE PERNET

BETTY

BETTY UPRICHARD

CHARLES K. DOUGLAS

ORANGE-BUFF

CHAT. DE C. VOUGEOT

COLUMBIA

CUBA

COPPERY-RED

DAME EDITH HELEN

PINK

DUCHESS OF WELLINGTON

YELLOW

EDEL

WHITE

ELDORADO

YELLOW

ETOILE DE FEU

FLAME-YELLOW

\begin{tabular}{r} 
RED \\
CRIMSON \\
SCARLET \\
PINK \\
YELLOW \\
PINK \\
\hline PHORIA WHE \\
PINK \\
PINK \\
PINK \\
\hline YELLOW \\
BLUSH \\
PINK \\
RED
\end{tabular}

ETOILE DE FRANCE

ETOILE DE HOLLANDE

FEU JOSEPH LOOYMANS

FRANCIS SCOTT KEY

GENERAL MCARTHUR

GRANGE COLOMBE

CREAM-YELLOW

GRUSS AN TEPLITZ

RED

HAWLMARK CRIMSON

HORTULANUS BUDDE

IMPERIAL POTENTATE

INDEPENDENCE DAY

JONKHEER J. L. MOCK

RED

RED

ORANGE

RED

RED

KAISERIN AUGUSTA VICTORIA WHITE

KILLARNEY QUEEN

LADY ALICE STANLEY

LADY ASHTOWN

LADY PIRRIE

LADY URSULA

LA FRANCE

LAURENT CARLE

LOS ANGELES

SALMON-PINK

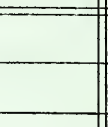

$\$ 1.25$

$\$ 1.50$

.90

1.25

1.00

.90

1.35

1.25

1.25

1.25

.90

1.50

1.00

1.00

1.50

1.00

.90

1.35

1.25

1.00

1.00

1.35

1.35

1.25

.90

1.00

1.00

.90

.90

1.50

1.35

1.25

1.10

1.10

1.10

.90

1.25

.90

.90

1.25

.90

1.25

.90

1.25

.90

1.10

.90

1.25

.00

1.10

.90

1.25

1.10

1.10

1.10

1.10

1.10

1.25 
PLEASE INDICATE IN FIGURES, IN COLUMNS MARKED "QUANTITY". HOW MANY OF EACH VARIETY ARE WANTED.
No. 1 GRADE Quantity Price

FORWARD

MME. BARDOU JOB

YELLOW

MME. BUTTERFLY

YELLOW-PINK

MME. CAROLINE TESTOUT

PINK

MME. EDOUARD HERRIOT

SALMON

MME. JULES BOUCHE

WHITE

MARG. MCGREDY ORANGE-VERMILION

MISS CYNTHIA FORDE

MISS LOLITA ARMOUR

MISS WILLMOTT

MRS. AARON WARD

MRS. A. R. BARRACLOUGH

MRS. CHARLES BELL

MRS. E. P. THOM

PINK

MRS. F. DENNISON

ORANGE

MRS. HENRY BOWLES

MRS. HENRY MORSE

MRS. WILLIAM C. EGAN

WHITE

YELLOW

PINK

PINK

YELLOW

BLUSH-WHITE

OPHELIA

YELLOW-BLUSH

PADRE

COPPERY-SCARLET

QUEEN OF FRAGRANCE

RADIANCE

RED RADIANCE

RED STAR

PINK

PINK

YELLOW-BLUSH

REV. F. PAGE-ROBERTS

PINK

SOUV. DE CLAUDIUS PERNET YELLOW SOUV. DE G. BECKWITH SALMON-PINK

TALISMAN

GOLDEN-YELLOW

VILLE DE PARIS

YELLOW

WILHELM KORDES COPPERY-SALMON

WILLIAM F. DREER BLUSH-YELLOW

WILLIAM R. SMITH

BLUSH

Speclal Hybrid Tea Collection (12 Sorts) Less $10 \%$ fall discount

Standard Hybrid Tea Collection (20 Sorts) Less $10 \%$ fall discount

EXTRA GRADE

TOTAL

Dollars Cents 
$10 \%$ DISCOUNT ON FALL SHIFMENTS.

PLEASE INDICATE IN FIGURES, IN COLUMNS MARKED "QUANTITY", HOW MANY OF EACH SIZE AND VARIETY A.RE WANTED.

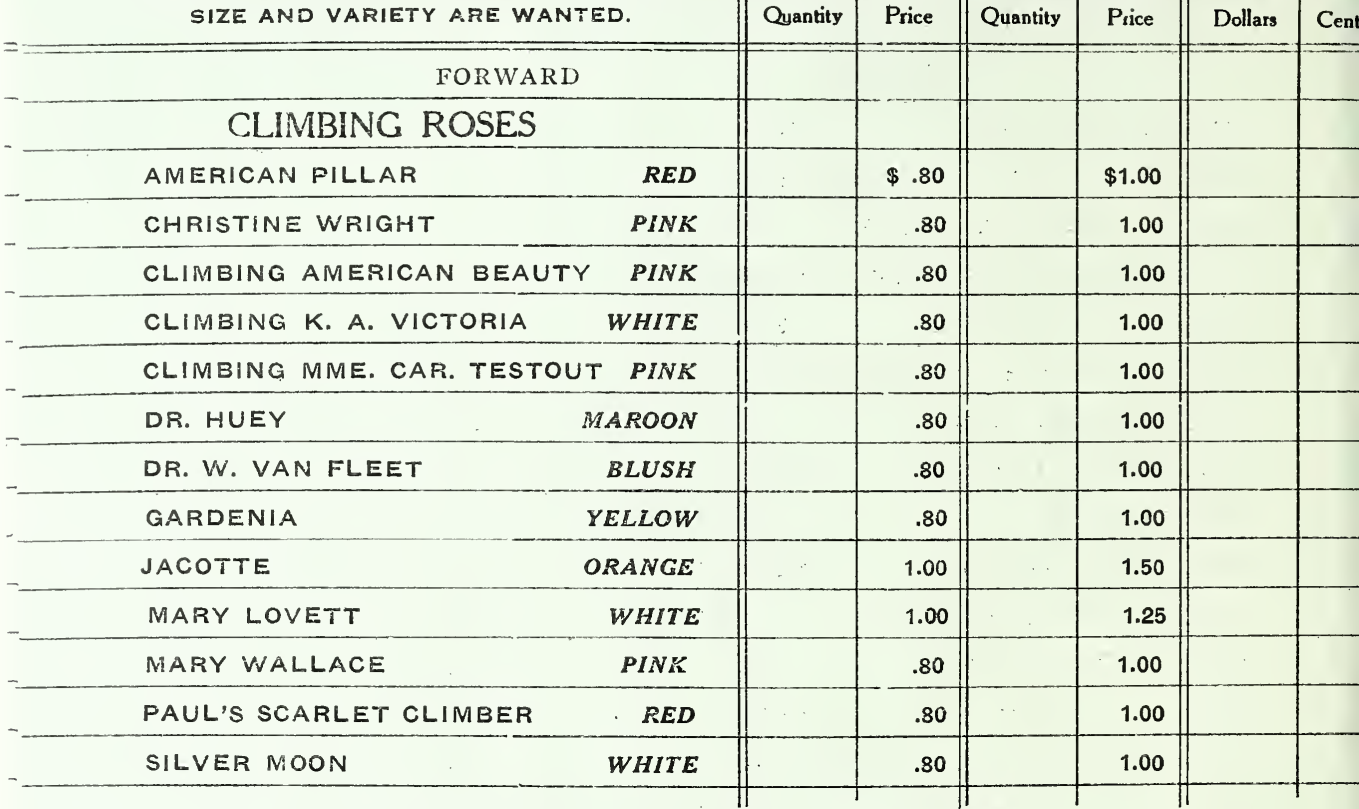

QUANTITY PRICES OF ROSES

Varieties priced at

$\$ .80$ each are $\$ 7.50$ per $10 ; \$ 65.00$ per 100 $\$ .90$ each are $\$ 8.00$ por $10 ; \$ 70.00$ per 100 $\$ 1.00$ each are. $\$ 9.00$ per 10 ; $\$ 80.00$ per 100 $\$ 1.10$ each are $\$ 10.00$ per 10 ; $\$ 85.00$ per 100 $\$ 1.25$ each are $\$ 11.00$ per $10 ; \$ 100.00$ por 100 $\$ 1.35$ each are $\$ 12.00$ per $10 ; \$ 110.00$ per 100 $\$ 1.50$ each are $\$ 13.50$ per $10 ; \$ 125.00$ per 100 $\$ 2.00$ each are $\$ 18.00$ per $10 ; \$ 160.00$ per 100 $\$ 2.50$ each are $\$ 22.50$ per 10

In order to obtain the 10-rate, order 10 or more roses in lots of 3 or more of each variety (not class) wanted. (EXAMPLE: If you order, say, 3 Clio, 3 Paul Neyron, 3 Columbia, 3 ophelia and 1 Radiance, you will be entitled to the 10 -rate on all but Radiance. In order to obtain the 100 -rate, order 50 or more roses in lots of 10 or more of each variety wanted. If in doubt, send in your order with the varieties carefully marked and we will net price it for you.

NO'tE:-When ordering, kindly state if we may or may not replace sold-out varieties with others equally as good; this refers chiefly to late Spring orders and for potted roses and will save delay by correspondence.

R MEMETER THAT QY ADDING 10 CENTS PER PLANT FOR ROSES PLANTED FALL 1929, WE INSURE YOU AGAINST ANY AND ALL LOSSES OVER THE FIRST WINTER AND UP UNTIL JURE FIAST, 1930.

INSURANCE DOES NOT APPLY TO ROSES PLANTED IN THE SPRING, BUT ANY REASONABLE COMPLAINTS DUE TO LOSSES FROM SPRING PLANTING WILL BE DULY CONSIDERED AND FULLY ADJUSTED. 


\section{Read Carefully Before Ordering}

When to Order. This catalogue is issued in September. The sooner you order after receiving catalogue, the more certain you will be of getting each and every variety you want as well as the choicest stock in everything ordered.

When We Ship. Fall shipping begins in early October to far northern points and to places where people are leaving their summer homes; the bulk of fall shipping is done during the last half of October and all of November. Our winter guarantee covers Roses planted any time this fall.

Spring shipping usually begins about March 15 to southern points and continues up until the end of April. After that we ship potted plants.

We ship by express unless otherwise instructed, buyer to pay transportation charges. Where it is necessary that shipment be made by parcel post, this will be done with small orders if sufficient money is sent to prepay postage. Larger orders can be packed more securely for shipment by express.

Substitutions. Please state what is to be done in case some variety is sold out on receipt of your order-whether you wish money returned or some equally valuable variety substituted.

Prices in this catalogue are net, and as low as goods of like quality can possibly be sold for. Remember that there is scarcely any article of merchandise in which the quality may differ so widely as in plants.

No order under $\$ 3$ can be accepted.

Remittances may be made by Bank Draft, Express or Post Office Money Order, Check, or Currency in Registered Letter, same to accompany order.

C. O. D. orders must be accompanied by a deposit of 25 per cent.

Charge Accounts. We are pleased to open a charge account if desired. Kindly tell us just a little about yourself or mention friends of yours who have dealt with us. In some cases it may be advisable to furnish your bank reference. No charge account opened for less than $\$ 10$.

If stock is not satisfactory upon delivery, it may be returned at once and your money will be refunded.

Complaints, if made immediately on receipt of goods, will be investigated, and, if due to any fault of ours, promptly satisfied. 


\section{GEORGE H. PETERSON INCORPORATED}

Rose and Peony Specialists

Fair Lawn, NewJersey, U.S.A. 